7-1-1999

\title{
The Legitimacy of International Governance: A Coming Challenge for International Environmental Law?
}

Daniel M. Bodansky

University of Georgia School of Law, bodansky@uga.edu

p bepress

\section{Repository Citation}

Daniel M. Bodansky, The Legitimacy of International Governance: A Coming Challenge for International Environmental Law? (1999),

Available at: https://digitalcommons.law.uga.edu/fac_artchop/443

This Article is brought to you for free and open access by the Faculty Scholarship at Digital Commons @ University of Georgia School of Law. It has been accepted for inclusion in Scholarly Works by an authorized administrator of Digital Commons @ University of Georgia School of Law. Please share how you have benefited from this access For more information, please contact tstriepe@uga.edu. 


\title{
THE LEGITIMACY OF INTERNATIONAL GOVERNANCE: A COMING GHALLENGE FOR INTERNATIONAL ENVIRONMENTAL LAW?
}

\author{
By Daniel Bodansky* \\ I. INTRODUCTION .
}

This article is about a problem only just becoming visible: the legitimacy of international environmental law, and more specifically, the perception that the international environmental process is insufficiently democratic. Until now, international lawyers have tended to focus on what environmental standards are needed and how those standards can be made effective. But as decision-making authority gravitates from the national to the international level, the question of legitimacy will likely emerge from the shadows and become a central issue in international environmental law. This article seeks to clarify the nature of the legitimacy challenge and to survey possible sources of legitimacy for international institutions.

The legitimacy of domestic government has been a central focus of political theory since at least the time of Hobbes and Locke. ${ }^{1}$ The liberal view of humans as free and rational individuals makes the very notion of authority problematic. As Rousseau asked, "If men are born free, what can justify their chains?"2 This is the question that modern theories of legitimacy seek to address. In contrast, the legitimacy of international governance has, until recently, received little attention. ${ }^{3}$ What accounts for this discrepancy? Why hasn't the legitimacy of international institutions been a bigger issue heretofore?

\footnotetext{
- Professor of Law, University of Washington. The author completed the research for this article as a Jean Monnet Fellow at the European University Institute in Florence. He wishes to thank Philip Alston, Richard Bilder, William Burke, David Caron, Joan Fitzpatrick, André Nollkaemper, David Victor, and Farhana Yamin for their many helpful comments and suggestions. Healso wishes to acknowledge the excellent research assistance of Soren Rottman.

' Stanley I. Benn, Authority, in I ENCYClOPEdia OF PHLOSOPHY 215 (Paul Edwards ed., 196'7); Richard E. Flathman, Legilimacy, in A COMPANIONTO CONTEMPORARYPOLITICALPHILOSOPHY 527 (RobertE. Guodin \& Philip Pettit eds., 1993). Earlier, authority was largely seen as deriving from God or from the natural order of social hierarchy and did not involve the imposition of one person's will on another.

${ }^{2}$ Benn, supra note 1, at 216 (paraphrasing Jean-Jacques Rousseau, The Social Contract, bk. I, ch. 1).

${ }^{3}$ The writers who have focused most clearly on the legitimacy of international institutions have been conservative critics, who have long argued that institutions such as the UN General Assembly are illegitimate because of the "one state, one vote" rule, which allows decisions to be made by countries that are themselves undemocratic and constitute only a small fraction of the world's population. See, e.g., Michael Lind, One Nation One Vote? That's Not Fair, N.Y. TIMES, Nov. 23, 1994, at A2 (criticizing UN General Assembly and World Trade Organization). Among the relatively few discussions of legitimacy by international lawyers are ABRAM CHAYES \& ANTONIA H. CHAYES, THE NEW SOVEREIGNTY: COMPLIANCE WITH INTERNATIONAL REGULATORYAGREEMENTS 127-34 (1995); ThOMAS M. FraNCK, THE POWER OF LEgTtIMACY AMONG NATIONS (1990); Jose E. Alvarez, The Quest for Legitimacy: An Examination of The Power of Legitimacy among Nations, 24 N.Y.U.J. INT'L L. \& POL. 199, $242-43$ (1991) (reviewing ThOMASM. FRANCK, THE POWER OF LEGTIMACYAMONG NATIONS (1990)).; David D. Caron, The Legitimacy of the Collective Authority of the Security Conncil, 87 AJIL 552, 558 (1993) (assessing legitimacy of Security Council); Phillip R. Trimble, A Revisionist View of Customary International Law, 33 UCLAL. REv. 665, 716-31 (1986) (questioning the legitimacy of customary international law). Discussions by international relations scholars include ERNST B. HAAS, WHEN KNOWLEDGE IS POWER 87-88 (1990); THE IMPLEMENTATION AND EFFICTIVENESS OF INTERNATIONAI ENVIRONMENTAL COMMTMENTS: THEORYAND PRACTICE (David G. Victor et al. eds., 1998); Inis L. Claude, Jr., Collective Legitimization as a Political Function of the United Nations, 20 INT'L ORG. 367, 372 (1966) (legitimacy of international organizations); Jerome Slater, The Limits of Legitimizalion in International Organizations: The Organization of American States and the Dominican Crisis, 23 INT'L ORG. 48, 52 (1969) (legitimacy of Organization of American States).
} 
The answer has two parts. First, until recently international institutions have generally been so weak - they have exercised so little authority - that the issue of their legitimacy has barely arisen. Indeed, many political scientists have questioned whether international institutions have any significant influence at all. ${ }^{4}$ Hence, international relations scholars have traditionally focused on the causal role-if any-of international institutions, rather than on their legitimacy. ${ }^{5}$

Second, to the extent that international institutions do influence the behavior of states-to the extent that we can speak of "international governance"-this authority has generally been self-imposed, it rests on the consent of the very states to which it applies. Theories of legitimacy focus on the problem of domination, the imposition of one's will on another. By contrast, the legitimacy of consensual obligations such as contracts or treaties is generally regarded as unproblematic. ${ }^{6}$ For this reason, many (if not most) modern theories of legitimacy attempt to base governmental authority on the consent of the governed. In international law, the strongly consensualist basis of obligation has tended to moot the issue of legitimacy.

As international institutions gain greater authority, however, and their consensual underpinnings erode, questions about their legitimacy are beginning to be voiced. The reinvigoration of the Security Council following the end of the Cold War, for example, has raised concerns about the Council's authority under the UN Charter to make decisions that bind all UN member states, even those that disagree. ${ }^{7}$ Although the Security Council's decision-making authority has a consensual origin-the acceptance by the member states of the UN Charter-the relationship between consent and authority has become too attenuated to provide an unproblematic basis of legitimacy, particularly given the domination of the Security Council by its five permanent members. So the question arises: Can the Council's authority be legitimated on some other basis? Is it justified, for example, by the Council's composition and voting rules? ${ }^{8}$ Similarly, the strengthened system of dispute resolution under the GATT Uruguay Round Agreements, which created the World Trade Organization (WTO), has raised questions about the de facto authority of the WTO to override domestic environmental and health laws. ${ }^{9}$

The emergence of legitimacy as an issue of international governance is, of course, most pronounced in the European Union, where the push for greater integration-and the concomitant transfer of regulatory authority from the national to the European level-has engendered widespread concern about a so-called "democratic deficit" in EU decision making. ${ }^{10}$ As one commentator notes, "The very fact that [legitimacy is a central concern]

\footnotetext{
${ }^{4}$ See, e.g., Hans J.Morgenthau \& KenNethN.Thompson, Politics among Nations: TheStruggle forPower AND PEACE (6th ed. 1985); Susan Strange, Cave! hic dragones: A Critique of Regime Analysis, in INTERNATIONAL REGIMES 337 (Stephen D. Krasner ed., 1983).

${ }^{5}$ See, e.g., ORAN R. YOUNG, COMPliANCE AND PuBlic AuthoRITY: A THEORYWITH INTERNATIONAL APPLICATIONS (1979) (no discussion of legitimacy as basis of compliance).

${ }^{6}$ Although consent represents a firm basis of popular legitimacy, from a philosophical standpoint, consent theory raises considerable difficulties. See generally LESLIE GREEN, THE AUTHORITY OF THE STATE (1988); Hanna Pitkin, Obligation and Consent-I, 59 AM. POL. SCI. REV. 990, 991 (1965).

${ }^{7}$ U.N. CHARTER, Art. 25 (states agree to carry out the decisions of the Security Council).

${ }^{8}$ See Caron, supra note 3; Sean D. Murphy, The Security Councib Legitimacy, and the Concept of Collective Security after the Cold War, 32 Colum.J. TRANSNAT'L L. 201, 246-69 (1994); Burns H. Weston, Security Council Resolution 678 and Persian Gulf Decision Making: Precarious Legitimacy, 85 AjIL 516 (1991).

9 JEREMY RABKIN, WhY SOVEREIGNTY MATTERS 1 (1998); Patti Goldman, The Democratization of the Development of United States Trade Policy, 27 CORNELL INT'L L.J. 631 (1994) (questioning legitimacy of WTO); David A. Wirth, Reexamining Decision-Making Processes in International Environmental Law, 79 IOWA L. REV. 769 (1994).

${ }^{10}$ The burgeoning literature on the "democratic deficit" - and, more generally, the problem of legitimacy in the European Union-includes: THE EUROPEAN UNION: HOW DEMOCRATIC Is Ir? (Svein S. Andersen \& Kjell A. Eliassen eds., 1996); DEMOCRAGY AND THE EUROPEAN UNION (Andreas Føllesdal \& Peter Koslowski eds., 1998); EUROPEAN IDENTITYAND THE SEARCH FORLEGTIMACY (Soledad Garcia ed., 1993); Klaus Armingeon, The Democratic Deficit of the European Union, 50 AUSSENWIRTSCHAFT 67 (1995); Gráinne de Búrca, The Quest for Legitimacy in the European Union, 59 MOD. L. REv. 349 (1996); Renaud Dehousse, Constitutional Reform in the European Community:
} 
at all is significant. We do not use this language when we think of other Treaty arrangements between states. . . That we do so in this context bears testimony to the acceptance by the major players that the Community requires a form of legitimation which can no longer be found purely in the traditional language of state agreement and state control." Most observers accept that further integration will depend on making the European Union more democratic (and thereby more legitimate), ${ }^{12}$ although there is little agreement about what that means.

Needless to say, international environmental law is nowhere near so far along the developmental path traveled by the European Union. At present, international environmental regimes exercise relatively little authority. They lack institutions with broad legislative powers, like the European Council of Ministers, or with compulsory jurisdiction to resolve disputes, like the European Court of Justice. Moreover, they lack the doctrines of supremacy and direct effects, which make European Community law supreme over national law and directly applicable by national courts. Unlike the European Union, which is rapidly developing into a constitutional order, international environmental law remains rooted within the voluntarist tradition of international law.

Despite these differences, the European Union debate is illuminating. It casts into sharper relief issues that are present, if only in embryonic form, in international environmental law. Moreover, it offers a preview of the sorts of concerns that are likely to emerge if problems such as climate change and loss of biological diversity intensify in coming years, and pressures grow to develop stronger international institutions in response-institutions with real authority to develop, apply, and enforce legal rules. Just as the European Union's alleged democratic deficit was a significant factor in the controversy about the Maastricht Treaty and its initial rejection by Danish voters in 1992, concerns about legitimacy could hinder efforts to strengthen international environmental governance.

-Already one can hear echoes of the EU debate. ${ }^{13}$ Climate change skeptics have voiced fears that the 1997 Kyoto Climate Protocol would involve a surrender of U.S. sovereignty to an unelected international authority. ${ }^{14}$ Some environmentalists have deplored the "democratic deficit" in international institutions resulting from a lack of public participation, ${ }^{15}$ and they have questioned the authority of semiautonomous standard-setting organizations such as the International Organization for Standardization (ISO) ${ }^{16}$ and the Codex Alimentarius Commission. ${ }^{17}$ And, during the preparations for the 1992 Earth

Are There Alternatives to the Majoritarian Avenue? 18 W. EUR. POL. 118 (1995); Heinz Hauser \& Alexia Müller, Legitimagy: The MissingLink for ExplainingEU-Instilution Building, 50 AUSSENWIRTSCHAFT 17 (1995); Giandomenico Majone, Europe's Democratic Deficit': The Question of Standards, 4 EUR. L.J. 5 (1998); J. H. H. Weiler, Eutropean Democracy and Its Critique, 18 W. EuR. POL. 4 (1995).

" P. P. Craig, Democracy and Rule-making Within the EC: An Empirical and Normative Assessment, \$ EUR. L.J. 105, 112-13 (1997).

${ }^{12}$ See, e.g., Dehousse, supra note 10, at 131 ("Only by bringing [the EU] closer to standards of European democracy can one hope to restore its credibility in the eyes of the general public."); Philippe Schmitter, Is $I l$ Really Possible to Democratize the Euro-Polity? in DEMOCRACY AND THE EUROPEAN UNION, supra note 10, at 14 n.5.

${ }^{13}$ See, e.g., Hilary F. French, Strengthening International Governance, 3 J. ENV'T \& DEV. 65 (1995); Goldman, stupra note 9; Kal Raustiala, Democracy, Sovereignty, and the Slow Pace of International Negotiations, 8 INT'1. ENVIL. AFF. 3 (1996).

${ }^{14}$ Jack Kemp \& Fred L. Smith Jr., Beware of the Kyoto Compromise, N.Y. TIMES, Jan. 13, 1998, at A.25.

${ }^{15}$ Katy Brady, Aarhus Convention Signed, 28 ENVTL. PoL'Y \& L. 171, 173 (1998) (quoting Brennin Van Dyke of the Center for International Environmental Law). On the importance of participation in international environmental regimes, see THE IMPLEMENTATION AND EFFECTIVENESS OF INTERNATIONAL ENVIRONMENIAL COMMTMENTS, supra note 3; Jonas Ebbesson, The Notion of Public Participation in International Environmental Law, 1997 Y.B. INT'L ENVTL. L. 51 (1998).

${ }^{16}$ Naomi Roht-Arriaza, Shifting the Point of Regulation: The International Organization for Standardization and Global Lawmaking on Trade and the Environment, 22 ECOLOGY L.Q. 479 (1995).

${ }^{17}$ The UN Food and Agriculture Organization (FAO) and the World Health Organization (WHO) jointly established the Codex Alimentarius Commission in 1962, in order to develop international food sifety standards. See generally Donna L. Malloy, The Codex Alimentarius Provides International Standards for Food Production and Safely, 12J.AGRIC. TAX'N \&L. 334-4I (1991); Lewis Rosman, Public Participation in International Pesticide Regulation: When 
Summit, some developing states challenged the voting rules used in the pilot phase of the Global Environment Facility (GEF), which gave control to donor countries.

These kinds of concerns will become louder and more widespread if, as appears likely, environmental decision-making authority continues to shift from the national to the international level-particularly if international institutions are compelled to depart from purely consensual modes of decision making in order to avoid gridlock and least-commondenominator outcomes. Already, the Montreal Protocol allows some of its regulations to be "adjusted" by qualified majority vote. ${ }^{18}$ Concern about global environmental problems has prompted calls for more such legislative mechanisms-calls emanating not just from environmental groups but from political leaders as well. In 1989, seventeen heads of state endorsed the Hague Declaration, which called for "new institutional authority" that involves non-unanimous decision making, in order to combat global climate change. ${ }^{19} \mathrm{It}$ is hard to imagine how problems such as global climate change will be successfully addressed, without the eventual establishment of more authoritative international institutions to set standards and oversee compliance.

The EU debate illustrates one important basis of legitimacy: democracy. Indeed, although dissatisfaction with democracy is common in Western countries, ${ }^{20}$ it is still no exaggeration to say that democracy has become the touchstone of legitimacy in the modern world. Not surprisingly, demands for greater "democracy" in international environmental law have begun to be voiced. ${ }^{21}$ But "democracy" can mean many different things-popular democracy, representative democracy, pluralist democracy, or deliberative democracy, to name a few. What might it mean in the context of international environmental law? Democracy among states or among people? A system of majority decision making or simply greater participation and accountability? And if the latter, participation by whom and accountability to whom? Abraham Lincoln once characterized democracy as government "of the people, by the people, and for the people." But who are "the people" in this connection?

Although democracy is now widely regarded as the primary basis of governmental legitimacy, other bases of legitimacy persist. During the controversy in the spring of 1998 over the selection of the first president of the new European Central Bank, most commentators seemed to feel that "independence" is also an important value, that needs

the Codex Commission Decides, Who Will Listen?, 12 VA. ENVTL. L.J. 329 (1993); David G. Victor, Effective Multilateral Regulation of Industrial Activity: Institutions for Policing and Adjusting Binding and Nonbinding Legal Commitments (1997) (unpublished Ph.D. dissertation, Massachusetts Institute of Technology) (on file with author). The term "codex alimentarius" is Latin for "food code." Although Codex standards are only recommendations, and states are under nolegal obligation to adopt them, the GATT Uruguay Round agreements establish them as reference standards. National standards that are equivalent to international (i.e., Codex) standards are presumed to be GATT-compliant, while standards exceeding Codex standards require additional support, in particular, scientific evidence. This has led some commentators to question the legitimacy of the Codex process. For example, Rosman somewhat hyperbolically asserts that "the Codex regime threatens the legitimacy essential to maintaining a system of regulatory decision making in a democratic society." Rosman, supra, at 363.

${ }^{18}$ Montreal Protocol on Substances That Deplete the Ozone Layer, Sept. 16, 1987, Art. 2(9), 26 ILM 1541 (entered into force Jan. 1, 1989) [hereinafter Montreal Protocol] (allowing control measures to be "adjusted" by a vote of two-thirds of the protocol parties, representing a majority of both developed and developing country parties); see infra note 64 and accompanying text.

${ }^{19}$ Declaration Adopted at The Hague, March 1989, reprinted in UN Doc. A/44/340-E/1989/120, Annex 5; see also Geoffrey Palmer, New Ways to Make International Environmental Law, 86 AJIL 259 (1992). Some environmental alarmists have suggested that global environmental problems will ultimately necessitate authoritarian responses. E.g., WILLIAM OPHULS, ECOLOGYAND THE POLITICSOF SCARCITY (1977); see generally.Wouter Achterberg, Can Liberal Democracy Survive the Environmental Crisis?: Sustainability, LiberalNeutrality and Overlapping Consensus, in THE POLITICS OF NATURE: EXPLORATIONS IN GREEN POLITICAL THEORY 81 (Andrew Dobson \& Paul Lucardie eds., 1993).

${ }^{20}$ See Michael J. SANDEL, DEMOCRACy's Discontent: AMERICA IN SEARCH OF A PUblic PhILOSOPHY (1996).

${ }^{21}$ See TOM Athanasiou, Divided Planet: The ECOlOGy OF Rich AND POOR 26 (1996); French, supra note 13, at 65; Goldman, supra note 9; Phillip R. Trimble, Globalization, International Institutions and the Erosion of National Sovereignty and Democracy, 95 MrCH. L. REv. 1944, 1966 (1997) ("If international institutions are to acquire and exercise the sovereign powers required to respond to the negative forces of globalism, they... will have to become more democratic."); Wirth, supra note 9, at 802. 
to be safeguarded against "political" (i.e., democratic?) control. ${ }^{22}$ Indeed, while "democracy" is universally honored, public discourse reveals a deep ambivalence about its effectiveness. In the United States, where this ambivalence is perhaps greatest, non-partisan commissions have sometimes been used to tackle the tough problems that the democratic process seems unable, by itself, to resolve. ${ }^{23}$ These commissions draw on expertise and effectiveness as legitimizing factors, as an alternative (or at least a supplement) to representative, majoritarian government.

Work on the emerging problem of international legitimacy is only just beginning. By highlighting the problem and clarifying the issues, this article seeks to lay the groundwork for further research. Although it focuses on environmental law, it has implications for other areas of international law, whose increasing authority has prompted similar concerns about legitimacy. ${ }^{24}$ Part II clarifies the meaning and significance of the concept of legitimacy, defining it as a quality that leads people (or states) to accept authority-independent of coercion, self-interest, or rational persuasion-because of a general sense that the authority is justified. Part III examines the two bases of contemporary international law, namely state consent and legality. Part IV then explores why, in the future, these will provide an increasingly shaky foundation for international environmental law, as demands grow for stronger institutions to address exigencies such as climate change and as the boundary between international and domestic environmental law blurs. Finally, part V surveys several potential bases of legitimacy, including democracy, public participation, and expertise.

The article's provisional message is cautionary. It proposes no compelling basis of legitimacy. Democracy - at least as we usually use the term-does not seem to be an option, given the lack of a global "demos," a lack that makes suggestions to establish a global parliament or to hold global referenda ${ }^{25}$ not only utopian but unwise. Principles of procedural fairness-transparency, public access, and so forth-are important, but do not answer the crucial question of who should make decisions and how they should do so. Finally, expertise can play an important role in legitimizing international environmental decision making, but ultimately many of the most important questions will require value judgments, not simply technical solutions. Unless some other source of legitimacy can be found, international environmental law must continue to rely on its traditional foundations: self-interest, reciprocity, and consent. In the long run, this is likely to represent a limiting factor on efforts to develop stronger and more effective international regimes.

\section{WHAT IS LEGITIMACY AND WHY DOES IT MATTER?}

The term "legitimacy" has been used in such various, ${ }^{26}$ and often nebulous, ways ${ }^{27}$ that it is useful to begin with some general observations about its meaning. As I shall use the term,

${ }^{22}$ Political Sparks Fly over Euro, INT'L HERALD TRIB., Apr. 27, 1998, at 1; see also Laurence Gormley \& Jakob de Haan, The Democratic Deficit of the European Central Bank, 21 EUR. L. REV. 95 (1996).

${ }^{23}$ For example, closing military bases and reforming Social Security.

${ }^{24}$ See, e.g., Jeffery Atik, Identifying Antidemocratic Outcomes: Authenticity, Self-Sacrifice and International Trade, $19 \mathrm{U}$. PA.J. INT'L ECON. L. 229 (1998) (trade law); Caron, supra note 3; Krishna Jayakar, Globalization and the Legitimacy of International Telecommunications Standard-Setting Organizations, 5 GLOBAL LEG. STUD.J. 711 (1998); Murphy, supra note 8.

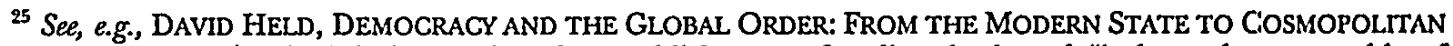
GOVERNANCE 269-74 (1995) (proposing the establishment of a directly-elected "independent assembly of democratic peoples").

${ }^{26}$ For example, sometimes "legitimate" means "genuine," as in such phrases as: "the Yankees are a legitimate contender for the title," or "the situation in Bosnia is a legitimate emergency." In other cases, "legitimate" means "justified," as in: "he raised a legitimate concern," or "she has a legitimate expectation of being paid."

${ }^{27}$ See, e.g, THOMAS M.FRANCK, FAIRNESS IN INTERNATIONAL LAWAND INSTITUTIONS 7, 22, 25, 26 (1995) (equating "legitimacy," inter alia, with procedural fairness, utilitarianism, a desire for order, and right process). Often "legitimacy" seems to be used as little more than a general term of support or approbation, like a "hurrah." One begins to suspect, as Hanna Pitkin notes, "that terms like 'legitimate, "authority," 'obligation' may' be parts of an elaborate social swindle, used to clothe those highway robbers who have the approval of society with a deceptive mantle of moralistic sanctity." Pitkin, supra note 6, at 991 . 
"legitimacy" refers to the justification of authority-the authority, for example, of legislatures to prescribe legal rules or of courts to decide cases. ${ }^{28}$ "Legitimate authority" simply means "justified authority," and theories of legitimacy attempt to specify what factors might serve as justifications-tradition, rationality, legality, and democracy, to name a few. ${ }^{29}$

The concept of "legitimacy" has both a sociological and a normative dimension. On the one hand, it refers to popular attitudes about authority. Authority has popular legitimacy if the subjects to whom it is addressed accept it as justified. The more positive the public's attitudes about an institution's right to govern, the greater its popular legitimacy. International institutions such as the climate change regime or the World Trade Organization affect the behavior of both states and individuals; hence the attitudes of either might be relevant in assessing their popular legitimacy. On the other hand, "legitimacy" can also have a normative meaning, referring to whether a claim of authority is well founded-whether it is justified in some objective sense. An institution such as the Security Council or the World Trade Organization is normatively legitimate if there are good reasons in support of its claims to authority, and illegitimate if not. ${ }^{30}$

Since persuasion is one of legitimacy's functions (perhaps, even, its primary function), the two aspects of legitimacy are closely related. We call a regime "legitimate" in order to persuade people (or states) to accept it, and we criticize it as "illegitimate" in the hope of undermining its authority. ${ }^{31}$ Indeed, some liberal theories of legitimacy draw a closer link between popular and normative legitimacy, by making popular acceptance an important or even necessary element of a regime's normative justification. ${ }^{32}$

\footnotetext{
28 "Authority," in turn, means "the right to command, or give an ultimate decision." 1 Oxford English Dictionary 572 (1933). To claim authority is to assert the right to direct others, while to actually exercise authority is to have that claim accepted. In accepting another's authority, one defers to the other's directives, independent of coercion or rational persuasion, because of some perceived quality orattribute of the entity exercising authority-charisma, moral rectitude, expertise, or legal office, to name a few. $C f$. HANNAH ARENDT, BETWEEN PAST AND FUTURE: EIGHT EXERCISES IN POLITICAL THOUGHT 93 (1968) ("If authority is to be defined at all ... it must be in contradistinction to both coercion by force and persuasion through arguments."); DAVID P. GAUTHIER, PRACTICAL REASONING: THE STRUCTUREAND FOUNDATIONS OF PRUDENTIAL AND MORALARGUMENTSAND THEIR EXEMPLIFICATION IN DISCOURSE 136 (1963) (appeals to authority and to reason are alternatives).

${ }^{29}$ For some representative definitions of legitimacy, see ARCHIBALD COX, THE ROLE OF THE SUPREME COURT IN AMERICAN GOVERNMENT 103 (1976) (legitimacy is the ability "to command acceptance and support from the community so as to render force unnecessary"); ROBERT A. DAHL, MODERN POLITICALANALYSIS 41 (2d ed. 1970) ("A government is said to be 'legitimate' if the people to whom its orders are directed believe that the structure, procedures, acts, decisions, policies, officials or leaders of government possess the quality of 'rightness,' propriety or moral goodness - the right, in short, to make binding.rules."); JÜRGEN HABERMAS, COMMUNICATION AND THE EVOLUTION OF SOCIETY 178 (T. McCarthy trans., 1979) ("Legitimacy means that there are good arguments for a political order's claim to be recognized as right and just; a legitimate order deserves recognition. Legitimacy means a political order's worthiness to be recognized"); SEYMOUR MARTIN LIPSET, POLITICAL MAN: THE SOCIAL BASES OF Polrrics 77 (1959) (legitimacy means "the capacity of the system to engender and maintain the belief that the existing political institutions are the most appropriate ones for the society"); Joseph Raz, Authority andJustification, 14 PHIL. \& PUB. AFF. 3, 5 (1985) (institutions have "legitimate authority only if and to the extent that their claim [to have a right to rule] is justified"). In contrast, Thomas Franck's influential book, The Power of Legitimacy Among Nations, supra note 3, has a somewhat different focus. It examines the effective authority of individual legal norms, rather than the justification of international institutions or decision-making processes. Thus, Franck focuses on several factors (for example, determinacy) that seem to have little to do with the justification of authority, but which may affect a norm's ability to influence conduct. Conversely, he devotes comparatively little space to the topic of this article, namely how the authority of international regimes might be justified-for example, on the basis of democratic decision making, state consent, public participation, or expertise. Of Franck's four legitimacy factors, the only one that relates to justification is "adherence" - the property of being duly enacted in accordance with the legal system's secondary rules-which I will discuss below under the rubric, "legal legitimacy." See supra note 48 and accompanying text. Despite initially defining legitimacy in terms of "right process," virtually none of his analysis focuses on such procedural issues as transparency, deliberation, elections, voting, and so forth.

${ }^{30}$ Hanna Pitkin, Obligation and Consent-II, 60 AM. POL. SCI. REv. 39 (1966) ("Legitimate authority is precisely that which ought to be obeyed, ... to which rational men considering all relevant facts and issues would consent ..." $)$.

${ }^{31}$ Thomas Nagel, Moral Conflict and Political Legitimacy, 16 PHIL. \& PUB. AFF. 215, 218 (1987); Claude, supra note 3 , at 372.

${ }^{32}$ See Achterberg, supra note 19, at 91.
} 
Nonetheless, the two aspects of legitimacy are both conceptually and practically distinct. There is a conceptual difference between saying, "the Security Council is legitimate," and "the Security Council is accepted as [or perceived as] legitimate." The first is an evaluative statement about the Security Council itself, the second an empirical one about popular (or governmental) attitudes. The evaluative issue has been the concern of political theorists and philosophers, ${ }^{33}$ the empirical issue that of social scientists (most importantly, of course, Max Weber) ${ }^{34}$

Although some theories of legitimacy make normative legitimacy depend, in part, on popular attitudes about governmental authority, if normative legitimacy were entirely reducible to popular legitimacy-if nothing were legitimate or illegitimate, but thinking made it so-there would be no basis for attempting to persuade people to change their views. A normative argument about the legitimacy of the Security Council may draw on factual data about popular beliefs, but it need not be confined to such data; it can employ such normative criteria as fairness, justice, consent and so forth. Consequently, the two types of legitimacy need not correspond. People may, in fact, accept authority based on tradition or myth or demagoguery. But this does not mean that such popular attitudes are justified. ${ }^{35}$ Thus, it is not inconsistent to say that an authority is justified but not popularly accepted (Weimar Germany?), or popularly accepted but not justified (Nazi Germanyl).

In discussing authority and legitimacy, we sometimes speak of the authority of an ongoing institution-for example, the World Trade-Organization or the climate change regime-and sometimes of the authority of a specific rule or decision-for example, the International Whaling Commission's (IWC) decision to impose a moratorium on commercial whaling or the Security Council's decision to authorize the use of military force against Iraq. In connection with the latter, it is important to bear in mind that what requires justification is the rule or decision's authority, not its particular content. ${ }^{36} \mathrm{~A}$ person might think that a law or a decision is misguided, or inequitable, or even unjust, but still accept it as legitimate-for example, on the ground that it was duly enacted by a democraticallyelected legislature or was made by a court with proper jurisdiction. ${ }^{37}$ Legitimacy does not depend on whether a rule or a decision is substantively correct (judged by whatever standard); rather, it reflects more general support for a regime, which makes subjects willing to substitute the regime's decisions for their own evaluation of a situation. Accordingly, definitions of legitimacy typically focus on ongoing systems of governance-on the institutions that issue directives and the processes by which they do so-rather than on the legitimacy of particular directives.

Whether an institution or regime is normatively legitimate-whether it is worthy of support-is an important question in and of itself. In contrast, a regime's popular legitimacy

\footnotetext{
${ }^{33}$ Indeed, much of Western political theory since the time of Hobbes and Locke has been concerned with the legitimacy of governmental authority.

${ }^{34}$ According to Weber, legitimacy is a sense of duty, obligation, or oughtness towards rules, principles, or commands. Martin E. Spencer, Weber on Legitimate Norms and Authority, 21 BRrT. J. Soc. 123, 126 (1970); see also Claude, supra note 3, at 369 (equating legitimacy with capacity to elicit approval); Slater, supra note 3, at 52 (legitimacy can be defined in terms of diffuse support); Martin Wight, International Legitimacy, in SYSTEMS OF STATES 153 (Hedley Bull ed., 1977) (equating international legitimacy with international acceptance and recognition by other states).

${ }^{35}$ For example, Franck claims that, as an empirical matter, governments perceive a rule as more legitimate if it receives "symbolic validation." FRANCK, supra note 3, at 91-110. But, even if this claim is empirically accurate, symbolic validation does not necessarily contribute to the normative legitimacy of the rule.

${ }^{36}$ See GrEEN, supra note 6, at 41 (discussing H. L. A. Hart). On this basis, it is possible to distirguish between the legitimacy of the impeachment process of President Clinton, and whether Clinton should in fact be impeached and removed from office.

${ }^{37}$ Raz, supra note 29 , at 13 ("The fact that an authority requires performance of an action is a reason for its performance which ... should exclude and take the place of [all other relevant reasons when assessing what to do]."). Similarly, when one accepts the authority (jurisdiction) of a court or an arbitrator, one agrees to accept its decision, whether or not one believes the decision to be correct.
} 
is instrumentally important, since legitimacy represents a potentially important basis of effectiveness, in addition to power and self-interest. As Weber emphasized, the more an institution is perceived as legitimate, the more stable and effective it is likely to be. ${ }^{38}$ Thus, writers speak not only of the legitimacy of power, but of the power of legitimacy. ${ }^{39}$ David Caron suggests, for example, that the perceived legitimacy of the Security Council can affect its ability to adopt decisions, the strength of those decisions, and the ability of states to build domestic support to carry them out. ${ }^{40}$ Similarly, questions about the legitimacy of the climate change regime or the International Whaling Commission or the Antarctic Treaty System may make states less willing to utilize these institutions or to accept and implement their decisions. ${ }^{41}$

Of course, popular legitimacy is not the only, or perhaps even the most important, source of effectiveness. People (or states) accept or reject an institution or rule for many different reasons; rarely do we encounter "pure" authority, untainted by any alternative basis of compliance. ${ }^{42}$ Separating out their relative importance is an extremely difficult, if not impossible, task. My claim is only that perceptions of legitimacy are an important basis of effectiveness and that, consequently, whether international environmental regimes are perceived as legitimate will play an important role in their long-term success. ${ }^{43}$

\section{LEGITIMACY IN CONTEMPORARY INTERNATIONAL ENVIRONMENTAL LAW}

Legitimacy concerns the justification of authority; it provides grounds for deferring to another's decision, even in the absence of coercion or rational persuasion. Thus far,

${ }^{38}$ I MAX WEBER, ECONOMY AND SOCIETX 31 (Guenther Roth \& Claus Wittich eds., 1968); see also CHARLES L. BLACK, The PEOPLE AND THE COURT: JUdiCIAL REVIEW IN A DEMOCRACY 52 (1960) (calling the legitimacy of a government "the condition of its life"); FRANCK, supra note 3; HABERMAS, supra note 29, at 178-79 ("the stability" of [a political] order of domination (also) depends on its (at least) de facto recognition [as legitimate]").

39 FRANCK, supra note 3; Claude, supra note 3, at 368.

${ }^{10}$ Caron, supra note 3, at 558; see also Slater, supra note 3 , at 52 (the more an international organization is perceived as legitimate, the more likely its members will be to comply with directives even when not under any serious compulsion to do so).

${ }^{11}$ See, e.g., Mohamed Haron, The Issue of Antarctica-A Commentary, in ANTARCTIC ChalIENGE III, at 271, 275 (Rüdiger Wolfrum ed., 1988) ("The 'bottom line' concerning the survivability and workability of the Antarctic Treaty System is its ability to acquire legitimacy across a wide spectrum of the international community."); Richard Falk, The Antarclic Treaty System: Are There Viable Alternatives?, in THE ANTARCTICTREATYSYSTEM INWORLD POLITICS 399,412 (Arnfinn Jørgensen-Dahl \& Willy $\emptyset$ streng eds., 1991) ("It seems evident that the quality of future viability of ATS depends on its legitimacy in the eyes of the wider world community ... ").

${ }^{12}$ Rulers usually employ a variety of means to have their directives obeyed-force, threats, arguments, even pleas. By the same token, people (or states) may obey directives for a mix of different reasons. Some states may accept the Security Council's authority as legitimate; others such as Iraq may obey due to fear of punishment or calculations of self-interest. Moreover, these various bases of compliance often interrelate. Coerced compliance may become internalized over time and take on the character of legitimacy. Conversely, when an institution's authority is widely accepted by states as legitimate, that enhances its ability to employ other means of compliance such as coercion or persuasion. The ability of the Security Council, for example, to use force to compel countries such as Iraq to comply depends on its authority vis à vis other UN member states, who must carry out its will. The concepts of "authority" and "legitimacy" are what Max Weber called "ideal types," abstractions that represent one component of reality. See H. H. Gerth \& C. Wright Mills, Introduction to FrOM MAX WEBER: ESSAYS IN SOCIOLOGY 59 (H. H. Gerth \& C. Wright Mills eds., 1946).

${ }^{13}$ Alan Hyde has critiqued empirical attempts to establish a causal link between legitimacy and effectiveness. Alan Hyde, The Concept of Legitimation in the Sociology of Law, 1983 WIS. L. REv. 379 (1983). Tom Tyler's work, however, suggests that beliefs about legitimacy do in fact contribute to obedience. TOM TYLR, WHY PEOPLE OBEY THE LAW (1990). For some illustrations of the widely-shared assumption that legitimacy matters, see R.W. Apple Jr., Now, The People Will Have a Chance to Judge, N.Y. TIMES, Sept. 12, 1998, at A1 (even if Clinton survives the Lewinsky scandal, "his moral leadership, that intangible legitimacy that makes a President a force in the country, has been shattered"); Michael Wines, When Minds Do Not Meet, N.Y. TIMES, Aug. 31, 1998, at AI (Russia is a place where "the popularity of a leader-or his unpopularity-affects not only his power but also his legitimacy"). In drawing a link between popular legitimacy and effectiveness, we must be careful to identify criteria or indicators of legitimacy other than actual effectiveness. Otherwise, we run the risk of circularity, by making effectiveness part of the very definition of legitimacy ("legitimacy is the tendency to induce compliance in the absence of coercion or self-interest"), as Thomas Franck at times seems to do. See Robert O. Keohane, International Relations and International Law: Two Optics, 38 HARV. INT'L L.J. 487, 493 (1997). 
international environmental law has developed on a different basis, through a consensual rather than an authoritative process. States have negotiated and adopted international rules that they believe are in their self-interest, rather than recognize the rulemaking authority of international institutions. They realize that they cannot solve some transnational or global environmental problem through individual action, so they agree to collective action by means of a reciprocal exchange of promises-they agree, for example, to limit their use of ozone-depleting substances or to impose restrictions on the import and export of endangered species. ${ }^{44}$

Even in this consensualist, state-oriented model of international law, however, the phenomenon of authority plays an ancillary role-and thus the issue of legitimacy plays a role as well. To begin with, there is the continuing authority of norms, once states have consented to them. Why should a state continue to be bound by a norm, once its interests change and it no longer consents? To answer this question, we need some notion that states can bind themselves through promises-that consent is a legitimate basis of obligation, and that obligations persist over time.

In considering the legitimating role of state consent, two types of consent should be distinguished: (1) specific consent to particular obligations or decisions-for example, by ratifying a treaty, joining consensus on a UN resolution, or accepting a court's jurisdiction in a particular case; and (2) general consent to an ongoing system of governance-for example, by ratifying a treaty such as the UN Charter, which creates institutions with quasilegislative and adjudicatory authority. ${ }^{45} \mathrm{~A}$ constitution confers general consent; a contract, specific consent. Thus far, specific consent has played the predominant role in the formation of international environmental law. States have specifically consented to the vast majority of international.obligations that bind them. They usually do so expressly-for example, by becoming a party to an agreement establishing particular obligations or by engaging in state practice that contributes to the formation of customary international law; in some cases, they do so tacitly-for example, by failing to object to a new norm as it comes into existence. By contrast, few existing international environmental obligations are the product of general consent. ${ }^{46}$ Among the exceptions are the "adjustments" adopted pursuant to the Montreal Protocol on Substances that Deplete the Ozone Layer, which allows a qualified majority of parties to tighten ("adjust") the controls on regulated substances. ${ }^{47}$

\footnotetext{
44 In this process, international institutions can serve important supporting functions-they can help focus international attention on an environmental problem, provide a forum for negotiations, enhance transparency, and channel assistance to states that lack the capacity to comply. See INSTITUTIONS FOR THE EARTH: SOURCES OF EFFECTIVE INTERNATIONAL ENVIRONMENTAL PROTECTION (Peter M. Haas et al. eds., 1993). But they rarely cxercise authority over states so as to raise concerns about legitimacy.

${ }^{45}$ The distinction I am drawing here is between consent to the secondary rules about how law is created, interpreted, changed, and applied and consent to the primary rules governing behavior. See H. L. A. HART, THE CONCEPT OF LAW 79-81 (2d ed. 1994). The different ways that a state may accept a court's jurisdiction also illustrate the difference between general and specific consent. On the one hand, a state may generally consent to a court's (compulsory) jurisdiction (for example, by means of the optional clause to the Statute of the International Court of Justice); on the other hand, it may specifically consent to a court's juriscliction to hear a particular dispute (for example, by means of a compromis).

${ }^{16}$ See Louis HENKIN, INTERNATIONAL LAW: POLITICS AND VALUES 26 (1995) (although "states could consent to lawmaking by majority... [or] by a representative body," instances of their doing so are "highly exceptional and limited ${ }^{n}$.

${ }^{47}$ Montreal Protocol, supranote 18, Art. 2(9). Outside the environmental arena, the Security Council is the most visible and important institution with nonunanimous decision-making authority, but other international institutions have similar authority in limited spheres. See generally Frederic L. Kirgis, Jr., Specialized Law-making Processes, in 1 THE UNITED NATIONSLEGAL ORDER 109 (Oscar Schachter \& Christopher C. Joyner eds., 1995); Wirth, supra note 9, at 791-97. For example, the International Civil Aviation Organization can adopt binding international standards for civil aviation over the high seas. Kirgis, supra, at 136. Similarly, the constitutive instruments for the World Health Organization, the International Atomic Energy Agency, and the World Bank can be amended by qualified majority vote. Wirth, supra note 9 , at 793-94.
} 
To the extent that authority is exercised at the international level by institutions rather than by international rules directly, then, in addition to general consent, we also need a concept of "legal legitimacy"- "the condition of being in accordance with law or principle," as the Oxford English Dictionary puts it. ${ }^{48}$ Legal legitimacy is what connects an institution's continuing authority to its original basis in state consent. The authority of the International Court of Justice, for example, derives from its Statute, to which UN member states consented. And the Court's continuing authority depends on its acting in accordance with the Statute. If it went outside or against the Statute, then its actions would lack legitimacy. The same would be true of decisions by the Security Council that exceeded its legal mandate under the UN Charter.

Generally, concerns about the legitimacy of international environmental regimes have related to one or both of these bases of legitimacy: state consent and legality. The challenge by Malaysia and other developing countries to the legitimacy of the Antarctic Treaty System (ATS), for example, concerns the former. At root, the issue is whether the decisions of the Antarctic Treaty parties have legitimacy vis à vis states that have not consented to the regime. ${ }^{49}$ Historically, membership in the Antarctic Treaty System has been quite limited, due to the Antarctic Treaty's "activities requirement," which requires states to engage in substantial activities in Antarctica in order to become Antarctic Treaty Consultative Parties (ATCPs) with full voting rights. ${ }^{50}$ Some developing countries have argued that a limited group of countries do not have the right to govern an area viewed by most states as part of the global commons, and they have advocated placing Antarctica instead under the auspices of the UN General Assembly.

The International Whaling Commission's moratorium on commercial whaling, in contrast, raises issues of legal legitimacy. ${ }^{51}$ The IWC imposed the moratorium pursuant to the International Convention for the Regulation of Whaling, which authorizes the regulation of whaling on a scientific basis, in order to make possible the orderly development of the whaling industry. ${ }^{52}$ In recent years, the IWC has refused to lift the moratorium, despite the finding of its Scientific Committee that the whaling of some species can safely be resumed. Whaling states charge that the IWC's action (or, more accurately, inaction) is illegitimate for two reasons. First, it is inconsistent with the objective stated in the Convention's preamble, namely to "make possible the orderly development of the

\footnotetext{
${ }^{18}$ This definition is based on the Latin root, "legitimus," which means lawful. Dolf Sternberger, Legitimacy, in 9 INTERNATIONAL ENCYCLOPEDIA OFTHE SOCIAL SCIENCES 244 (David Sills ed., 1968). The connection between law and legitimacy is fundamental to the idea of the rule of law, which makes political authority subject to the restraint of general, open, and relatively stable rules. See generally Joseph Raz, The Rule of Law and Its Virtue, 93 LAW Q. REV. 195 (1977); see also F. A. HAXEK, THE ROAD TO SERFDOM 54 (1944) (on rule of law); JERRY L. MASHAW, GREED, CHAOS AND GOVERNANCE: USING PUBLIC CHOICE TO IMPROVE PUBLIC LAW (1997) (legitimacy flows from rule of law). According to this view, a directive's authority derives from the fact that it was duly promulgated in conformity with more general, secondary rules for law creation (for example, the constitution in the case of legislation, an agency's organic statute for administrative rulemaking, or an international organization's constitutive treaty for any secondary legislation it may adopt). Similarly, an official's authority is not personal, but instead flows from her office, and must be exercised within the bounds of the pre-existing rules. A policewoman has a right to command, but only to the extent that she acts within the scope of her lawful authority. Franck calls this quality of legal rules "adherence." FrANCK, supra note 3, at 184. For Weber, legal-rational authority depended on the formal process of enactment of rules, not their specific content. In his view, belief in legality is "the essential basis of all stable authority in modern society." ROGER COTTERRELL, LAW'S COMMUNITY: LEGAL THEORY IN SOCIOLOGICAL. PERSPECTIVE 136 (1995); see also MAX WeBER, MAX WEBER ON LAW IN ECONOMY AND SOCIETY (Max Rheinstein \& Edward Shils trans., 1954).

${ }^{19}$ Arnfinn Jørgensen-Dahl, The Legitimacy of the ATS, in THE ANTARCTIC TREATY SYSTEM, supra note 41, at 287; GOVERNING THEANTARGTIC:THE EFFECTIVENESSAND LEGITIMACYOFTHEANTARCTIC TREATY SYSTEM (Olav Schram Stokke \& David Vidas eds., 1997).

${ }^{50}$ Antarctic Treaty, Dec. 1, 1959, Art. IX(2), 12 U.S.T. 794, 402 U.N.T.S. 71.

31 See generally CHAYES \& CHAYES, supra note 3, at 130; William Aron et al., Flouting the Convention, ATLANTIC MONTHLY, May 1999, at 22; David D. Caron, The International Whaling Commission and the North Atlantic Marine Mammal Commission: The Institutional Risks of Coercion in Consensual Structures, 89 AJIL 154 (1995).

${ }^{52}$ International Convention for the Regulation of Whaling, Dec. 2, 1946, preamble, 62 Stat. 1716, 161 UNTS
} 72. 
whaling industry." Second, it conflicts with the requirement that the Commission's actions be based on "scientific findings." ${ }^{\text {"I }}$ In essence, whaling states argue that a new preservationist regime is being imposed on them, different from the conservationist regime to which they consented when they joined the Whaling Convention. As one Norwegian critic of the IWC put it, whaling states signed on to play cricket, but now find themselves pressured to play a game of chess instead. ${ }^{54}$

The issue of legal legitimacy also underlies, at least in part, ${ }^{55}$ the criticisms by environmentalists of recent GATT/WTO decisions in trade and environment cases, which concluded that several US wildlife laws are inconsistent with the GATT ${ }^{56}$ The criticism is not simply that the GATT/WTO dispute resolution panels interpreted the GATT incorrectly. Instead, the issue is whether the decisions represent legitimate (justified) interpretations of the legal rules to which states consented. Environmental groups argue that the dispute resolution panels have illegitimately read out of existence GATT Article XX, which allows states to restrict trade for conservation purposes. Admittedly, there is a fine line between saying that a decision is merely mistaken and saying that it is illegitimate. But if a decision represents not a neutral interpretation of the GATT, but rather an imposition by a panel of its own trade-oriented views-through, say, an unreasonably narrow interpretation of Article XX-then this would cross the line into illegitimacy; it would not be "in accordance with law or principle."

\section{THE EMERgING PROBLEM OF LEgITIMACY IN INTERNATIONAL ENVIRONMENTAL LAW}

Apart from a few regimes such as the International Whaling Convention and the Antarctic Treaty System, state consent and legality have until now provided a relatively firm foundation for international environmental law. But two developments are likely to undermine their ability to do so in the future. First, the coming generation of environmental problems will probably require more expeditious and flexible lawmaking approaches, which do not depend on consensus among states. Second, to the extent that international environmental law is beginning to have significant implications for non- or substate actors (who have not consented to it directly), rather than just for the relations among states, state consent may for them have little legitimating effect. As international environmental law continues to grow more like domestic environmental law, it will be held to the same standards of legitimacy, and its lack of transparency and accountability will become increasingly problematic.

${ }^{53}$ Id. Art. V(2).

${ }^{54}$ Andrew Pollack, Commission to Save Whale Endangered Too, N.Y. TimEs, May 18, 1993, at C4.

${ }^{55}$ Environmentalists also argue that the WTO panel procedures do not give the public an adequate opportunity to participate, and that the panels are composed primarily of trade rather than environmental experts. See Goldman, supra note 9, at 693-97; Wirth, supra note 9, at 786-91.

${ }^{56}$ GATT Dispute Panel Report, United States-Restrictions on Imports of Tuna, B.I.S.D. (39th Supp.) at 155 (1993), reprinted in 30 ILM 1954 (1991); GATT Dispute Panel Report, United States-Restrictions on Imports of Tuna, June 16, 1994, GATT Doc. DS29/R, reprinted in 33 ILM 839 (1994); WTO Appellate Body, United States-Import Prohibition of Certain Shrimp and Shrimp Products, Oct. 12, 1998, WT/DS58/AB/R, reprinted in 38 ILM 118 (1999).

${ }^{57}$ This was the argument, for example, made by Earthjustice Legal Defense Fund in its Comments to the WTO Appellate Body in the WTO Shrimp-Turtle dispute. After discussing what it viewed as errors in the WTO panel report, Earthjustice argued that .

[t]ogether, these errors indicate that the Panel went beyond its legitimate dispute settlement role and authority to create new rules concerning the application of Article XX... . Such a task is inappropriate for a dispute resolution panel. Rather, the creation of new rules is a legislative function legitimate only to governments directly responsible to the people affected. Unless the Appellate Body corrects these mistakes, the Panel's report in this case will severely weaken public confidence in the legitimacy of the WTO ....

Earthjustice Legal Defense Fund, Comments to the Appellate Body of the World Trade Organization Concerning United States-Import Prohibition of Certain Shrimp and Shrimp Products, June 16, 1998, at 2. 


\section{Non-Consensus Decision-making Mechanisms}

As noted earlier, international environmental law has developed primarily through the negotiation of treaties that bind consenting states to rules rather than governance structures. In practice, this has usually meant an effort to find consensus, since states are reluctant to take action against global problems such as climate change or ozone depletion unless everyone (or nearly everyone) is required to do so; unilateral action simply raises a country's costs, thereby injuring its competitiveness, without necessarily solving the problem, if others continue to pollute.

Consensus decision making, however, involves numerous, by now familiar, problems. ${ }^{58}$ Attempting to achieve consensus is time-consuming and difficult. Agreements tend to be inflexible, given the difficulties of gaining agreement on any changes. Moreover, agreements must either represent the least-common-denominator, and thus be weak, ${ }^{59}$ or must create different obligations for different states. In many cases, reaching agreement at all is impossible, so a consensus requirement in effect precludes collective action. For these reasons, among others, within domestic society, "the unanimity rule is recognized as incompatible with effective government." 60

International environmental law has employed a variety of mechanisms to circumvent the "slowest boat" phenomenon associated with consensus decision making and thereby make possible more robust international standard-setting. ${ }^{61}$ But, despite some successes, most notably the ozone regime, ${ }^{62}$ the consensus requirement puts international environmental law under a serious handicap. It is difficult enough to enact domestic legislation to control water or air pollution in a system of simple majority rule, particularly when decisions impose significant costs on identifiable segments of society. But imagine trying to adopt such rules through a consensus mechanism. Consensus decision making is even less likely to be able to address international problems such as climate change, where states have (or at least think they have) very different interests, where the costs may be extremely high, and where the regime may need to change rapidly as scientific understanding of the problem improves. Instead, successful international action will depend on the ability to require common action even in the absence of consensus among states-it will depend, that is, on some form of supranational authority. ${ }^{63}$

Consider, for example, the ozone regime. Compared to climate change, the ozone problem is simple-the science is much better understood and, in most cases, replacement technologies exist at a reasonable cost. But even the ozone regime has found it desirable to provide for non-consensus decision making. The Montreal Protocol on Substances that Deplete the Ozone Layer states that, once a chemical is subject to control measures, those

\footnotetext{
${ }^{38}$ See Palmer, supra note 19, at 259 ("The existing methods [of international lawmaking] are slow, cumbersome, expensive, uncoordinated and uncertain. Something better must be found if the environmental challenges the world faces are to be dealt with successfully. ${ }^{n}$ ). But see Jonathan Baert Wiener, On the Political Economy of Global Environmental Regulation, 87 GEO. L.J. 749, 793 (1999) (“[A]dvocates of environmental protection should not necessarily be so quick to seek a coercive, legislative model for the global arena. The voluntary assent rule may be a bit like the tortoise, slow but steady, unperturbed by the distracting demands of self-serving enthusiasts along the way. A coercive rule may be more like the hare, faster but more prone to stray from the straight and narrow.").

${ }^{39}$ The Norwegian political scientist, Arild Underdal, has referred to this phenomenon as the "law of the least ambitious program." ARILD UNDERDAL, THE POLITICSOF INIERNATIONAL FISHERIES MANAGEMENT:THE CASEOF THE NORTHEAST ATLANTIC 36 (1980).

${ }^{60}$ CrOMWELl RICHES, MAjORITY RULE IN INIERNATIONALORGANIZATION: ASTUdYOFTHE TREND FROM UNANIMITY TO MAJORITY DECISION 7 (1940).

${ }^{61}$ These innovative mechanisms include rapid amendment procedures, provisional application of agreements pending entry into force, differential standards, and selective incentives. See PETER H. SAND, LESSONS LEARNED IN GLOBAL ENVIRONMENTAL GOVERNANCE (1990).

62 See RiCHARD E. BENEDICK, OZONE DiPLOMACY: NEW DIRECTIONS IN SAFEGUARDING THE PlaNET (2d ed. 1998).

${ }^{6 s}$ Palmer, supra note 19 at 278-82; of. Garrett Hardin, The Tragedy of the Commons, 162 SCIENCE 1243 (1968) (tragedy of the commons problems will require "mutual coercion, mutually agreed upon").
} 
controls may be tightened ("adjusted") by a qualified majority vote. ${ }^{61}$ This decision-making rule does not simply prevent a minority from blocking action; it subjects the minority to the majority's will. Adjustments bind all parties to the Montreal Protocol, not just those that give specific consent. In this regard, the Montreal Protocol's adjustment procedure constitutes an embryonic legislative mechanism, rather than merely a contractual mechanism by which states voluntarily assume obligations.

Non-consensus decision-making mechanisms may be even more crucial with regard to compliance issues. The 1997 Kyoto Climate Change Protocol, for example, calls for the establishment of a compliance mechanism to oversee implementation of the Protocol's commitments-in particular, the various mechanisms by which parties will be allowed to trade their allocations of greenhouse gas emissions. ${ }^{65}$ Some proposals envision a compliance body with broad authority to determine whether states are in compliance with their emissions commitments, and, if not, what the consequences should be (for example, buyer liability for trades of non-existent emissions allowances) ${ }^{66} \mathrm{But}$ it is difficult to see how such a procedure could work by consensus.

The use of non-consensus mechanisms is, of course, furthest advanced in the European Union. To make possible stronger EU action, and to avoid deadlock, the European Union has progressively moved from unanimity to qualified majority voting in the Council of Ministers. Under the current voting rules, most decisions require only sixty-two of the eightyseven total Council votes. ${ }^{67}$ Over time, more and more types of decisions have been made subject to this majority voting procedure.

In the field of international environmental law, proposals have already surfaced to establish new, more authoritative institutions, in order to address global problems such as climate change. ${ }^{68}$ In 1989 , representatives of twenty-four countries, including such major powers as Germany, Japan, India and France, adopted the Declaration of the Hague, which endorsed "the principle of developing . . . new institutional authority" involving nonunanimous decision making to address the climate change problem. ${ }^{69}$ More recently, New Zealand proposed in the United Nations the establishment of a global legislative body with the power to adopt environmental rules that bind all nations. ${ }^{70}$ Although the Hague Declaration is sometimes seen as a blind alley that has not led anywhere, what is striking is the adoption of the Declaration at all, not its lack of immediate results.

Are the existing foundations of international law sufficient to legitimate institutions with non-consensus decision-making authority? Certainly, legal legitimacy would not suffice. ${ }^{71}$ Legal legitimacy takes what might be called an internal perspective: particular directives are justified in terms of a regime's secondary rules about who can exercise authority, according to what procedures, and subject to what restrictions. But legal legitimacy does not address whether a regime's ongoing governance arrangements are themselves justified. The fact, for example, that Chapter VII of the UN Charter permits the Security Council to authorize

\footnotetext{
${ }^{64}$ Montreal Protocol, supra note 18, Art. 2(9).

${ }^{65}$ Kyoto Protocol to the UN Framework Convention on Climate Change, Art. 18, FCCC Conference of the Parties, 3d Sess., UN Doc. FCCC/CP/1997/7/Add.2.

${ }^{66}$ Suzi Kerr et al., Policy Options for Addressing Compliance Issues Raised by Emissions Trading, Center for Clean Air Policy report (Nov. 1998) (unpublished manuscript, on file with author).

${ }^{67}$ The Council uses a system of weighted voting, under which Germany, France, Italy and the United Kingdom have 10 votes each; Spain has 8 votes; Belgium, Greece, the Netherlands, and Portugal have 5 votes each; Austria and Sweden have 4 votes each; Ireland, Denmark and Finland have 3 votes each; and Luxembourg has 2 votes.

${ }^{68}$ For an early example of this approach to environmental problems, see RICHARD A. FALK, THIS ENDANGERED PLANET: PROSPECTS AND PROPOSALS FOR HUMAN SURVIVAL (1971).

${ }^{69}$ See supra note 19. At a press conference, Norwegian Prime Minister Gro Brundtland commented that " $[t]$ he principles we have endorsed are in fact radical, but anything less would not serve us." Edward Cody, Global Environmental Power Sought, WASH. POST, Mar. 12, 1989, at A27.

${ }^{70}$ Palmer, supra note 19 , at 279-80.

${ }^{71}$ Cf. Claude, supra note 3, at 369 (arguing against equation of legality and legitimacy).
} 
the use of force in former Yugoslavia does not answer the more fundamental question of whether the Council's composition and decision-making mechanisms are legitimate. ${ }^{72}$ Similarly, enactment of an EU regulation in accordance with the EU treaties is not enough to ensure its legitimacy, since that depends also on whether the governance arrangements established by those treaties are legitimate. ${ }^{73}$ To answer those questions, we need to step outside of the UN Charter or the EU treaties and evaluate their provisions based on some external standard of legitimacy.

To some degree, general consent could provide a basis of legitimacy for non-consensus decision-making mechanisms. States could agree to such a mechanism in a treaty, as they have done in the Montreal Protocol, the UN Charter, and the European Union agreements. ${ }^{74}$ From the perspective of social contract theory, this general consent should give these regimes a strong claim to legitimacy-indeed, a stronger claim than many national governments, since these regimes are based on actual contracts to which each member state gave its express consent, rather than on a merely hypothetical social contract. So long as a regime stays within its constitutional limits (i.e., has legal legitimacy), then states that freely consented to a non-consensus decision-making process should be bound by the results.

The persisting questions about the legitimacy of the European Union and the Security Council, however, suggest that general consent may not be sufficient, in itself, to legitimate a general system of governance or its resulting rules. General consent involves a much more significant surrender of autonomy than specific consent-and thereby raises more serious concerns about legitimacy-since, in giving consent, a state does not know what particular constraints may be imposed on it in the future. For this reason, the notion of "the consent of the governed" has come to mean more in modern political theory than simply initial, general consent to governmental authority; it implies ongoing consent through democratic elections. It requires, as P. H. Partridge notes, that "governments are made perpetually responsive to the ideas and demands of the governed."75 Although general consent may be sufficient to legitimate a relatively limited decision-making mechanism such as the Montreal Protocol adjustment procedure, where the range of possible decisions is narrowly circumscribed and the issues have a significant technical component, when an institution must be able to respond to changing problems in changing ways, "any concept of consent is unlikely to have any significant application . . . unless we conceive it as a process, as a relationship... that must be constantly renewed and maintained." ${ }^{76}$ That is why the consent of EU member states to the EU treaties, or of UN member states to the UN Charter, has not laid to rest questions about the legitimacy of the European Council or the Security Council respectively. By the same token, general consent in unlikely to be sufficient to legitimate

\footnotetext{
${ }^{72}$ See Murphy, supra note 8, at 248-49 (critics of the legitimacy of the Security Council look beyond whether Council is acting within its legal competence).

${ }^{73}$ Weiler's category of "formal (legal) legitimacy" is similar to what I am calling here simply "legal legitimacy." He states that "the notion of formal legitimacy in institutions or systems implies that all requirements of the law are observed in the creation of the institution or system. This concept is akin to the juridicial concept of formal validity." J. H. H. Weiler, The Transformation of Europe, 100 YALE L.J. 2403, 2468 (1991). But to avoid the problem posed by unjust laws, Weiler's category of "formal (legal) legitimacy" includes substantive (non-formal) elements, in particular, that the legal rules be created by democratic institutions and processes. Id. In contrast, my discussion keeps these two elements of legitimacy distinct.

${ }^{71}$ Id. at 2468-69. Despite occasional claims to the contrary, see, e.g., Prosper Weil, Towards Relative Normativity in International Law, 77 AJIL 413, 420 (1983) ("[T]here can be no question today, any more than yesterday, of some 'international democracy' in which a majority or representative proportion of states is considered to speak in the name of all and thus be entitled to impose its will on other states."), there is nothing in international law that prevents states from agreeing to governance arrangements that authorize the majority to make binding decisions. SeeWELIINGTON KOO,JR., VOTING PROCEDURES IN INTERNATIONAL POLTTICAL ORGANIZATIONS 10 (1947); RICHES, supra note 60, at 9.

${ }^{75}$ P. H. PARTRIDGE, CONSENT AND CONSENSUS 29 (1971).

${ }^{76}$ Id. at 29-30; see also HeNRY Sidgwick, THE Elements OF Pol.rTICs 610 (2d ed. rev., London, Macmillan 1897) (democracy should rest on the "active consent" of the governed).
} 
environmental institutions with broad decision-making powers, of the kind envisioned by the Hague Declaration.

\section{The Domestication of International Environmental Law}

That general state consent is insufficient to legitimate institutions with broad decisionmaking authority is perhaps unsurprising. More remarkable is the declining role of specific state consent in legitimating international governance.

The debate about legitimacy in the European Union again highlights this clevelopment. Until relatively recently, most EU action depended, in practice, on specific state consent. Under the so-called Luxembourg Compromise, the EU Council of Ministers could take actions affecting a state's vital interests only by unanimous agreement (despite the fact that the EU treaties provide for majority voting in the Council of Ministers). If specific consent were still a significant source of the European Union's legitimacy, then the progressive erosion of unanimous decision making in favor of majority voting should have been a major cause of the European Union's legitimacy crisis, and the reintroduction of a unanimity requirement in the Council a possible solution. ${ }^{77}$ In fact, however, the reverse seems to be true: proposals to reform the EU typically suggest reducing the role of specific state consent by further restricting the rèquirement of Council unanimity.

What accounts for the diminishing role of specific state consent in EU governance? The answer is plain if we ask, who is consenting on behalf of whom? In liberal theory, consent provides a clear basis of legitimacy when individuals bind themselves. But, in the European Union, this identity of ruler and ruled-which is the basis of selfgovernment-often does not exist. On the one hand, consent is expressed by a member state's executive branch, which represents the state in the European Union's Council of Ministers. On the other, EU measures increasingly govern the conduct of private actors. Given this situation, the question is whether the executive branch, through its consent to EU legislation, can legitimately bind private actors. ${ }^{78}$ This is a question that the traditional theory of state consent does not address. It focuses on the authority of international law vis à vis states, not the authority of states over individuals ${ }^{79}$ (which the theory of state consent treats as a matter of domestic $\operatorname{law}^{80}$ ).

The theory of state consent was relatively unproblematic so long as international law focused on a state's own behavior-primarily, its relations with other states. In consenting to international norms, a government-and, more specifically, the executive branch - usually bound only itself. ${ }^{81}$ But, increasingly, international environmental law has significant implications for non-state actors as well. The vessel construction and design standards established by MARPOL, for example, in effect govern the behavior of shipbuilders and owners. Similarly, fisheries regimes limit the activities of fishermen, and the ozone regime (though more indirectly) limits the industries that produce or use ozone-depleting

\footnotetext{
77 Weiler, supra note 73, at 2473; see also Dehousse, supra note 10, at 119 (describing proposals to solve the legitimacy crisis by strengthening the Council).

${ }^{78}$ In federal states, some commentators have raised a similar question about the extent to which the federal government can legitimately consent to international obligations that bind its constituent parts. See Curtis $A$. Bradley, The Treaty Power and American Federalism, 97 MICH. L. REv. 390 (1998) (questioning the legitimacy of international treaties vis à vis states of the United States):

${ }^{79}$ Cf. Paul B. Stephan, Accountability and International Lawmaking: Rules, Rents and Legitimacy, 17 INw.J. INI'L L. \& BUS. 681, 684 (1996-97).

${ }^{80}$ Vienna Convention on the Law of Treaties, May 23, 1969, Art. 46, 1155 UNTS 331 (internal law governs competence to conclude treaties).

${ }^{81}$ As Alexander Hamilton noted in The Federalist No. 75, treaties are "not rules prescribed by the sovereign to the subject, but agreements between sovereign and sovereign." THE FEDERALIST No. 75, at 450-51 (Clinton Rossiter ed., 1961).
} 
substances. $^{82}$ Indeed, it has become almost a commonplace that international environmental law addresses subjects that, in the past, were addressed by national law. ${ }^{83}$ The corollary is that the more international environmental law resembles domestic law, the more it should be subject to the same standards of legitimacy that animate domestic law. ${ }^{84}$

The inadequacy of state consent is, of course, most pressing with regard to people living in states that lack legitimacy domestically. As the EU legitimacy debate illustrates, however, even democratic states are not immune, to the extent that foreign policy decision making tends to be less "democratic" than domestic decision making-to the extent, for example, that the executive branch plays a stronger role or there is greater secrecy and the legislature exercises little or no control. ${ }^{85}$ If environmental standards are to be established through state consent to an international regime, rather than by means of domestic legislation, then it follows that environmental "foreign" policy needs to be "democratized"-it needs to be subject to the same safeguards and public accountability as domestic regulation. ${ }^{86}$ Otherwise, the danger exists that a state may not be an adequate representative of its people internationally. ${ }^{87}$

\section{Possible Alternative BASES OF Legitimacy}

Apart from state consent, what might justify international environmental institutions with greater rulemaking and enforcement authority? Although political philosophers and social

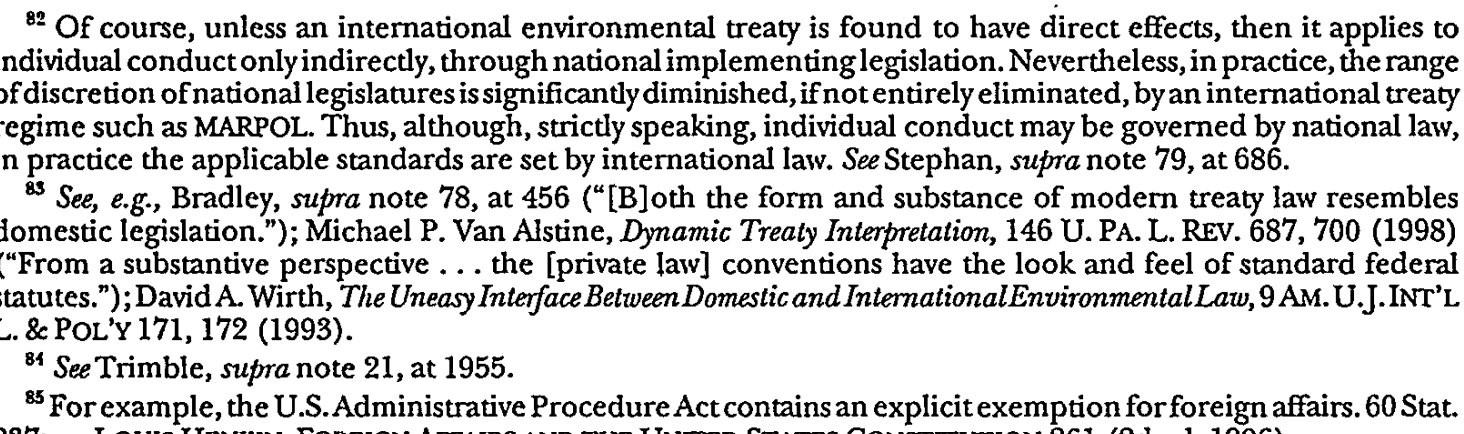
237; see LOUIS HENKIN, FOREIGN AFFAIRS AND THE UNITED STATES CONSTITUTION 261 (2d ed. 1996)

${ }^{86}$ See Wirth, supra note 83 ; Goldman, supra note 9.

${ }^{87}$ The rapid amendment procedure contained in many recent environmental agreements illustrates the insufficiency of state consent as a basis oflegitimacy. Traditionally, treaty amendments bound only those states that explicitly consented. Generally this consent was expressed through ratification, which in countries like the U.S. requires legislative approval. Many recent international environmental regimes depart from this model by establishing a system of tacit consent, pursuant to which amendments to technical annexes come into force automatically, following approval by the convention parties, except for those states that specifically opt out. See, e.g., Convention on International Trade in Endangered Species of Wild Flora and Fauna (CITES), dome March 3, 1973, Art. XV, 27 U.S.T. 1087, 993 UNTS 243; Convention for the Prevention of Marine Pollution by Dumping of Wastes and Other Matter, opened for signalure Dec. 29, 1972, Art. XV(2), 26 U.S.T. 2403, 1046 UNTS 120. Rapid amendment procedures have also been provided for in non-environmental treaties, including the UN Convention on the Prohibition of the Development, Production, Stockpiling and Use of Chemical Weapons and on their Destruction, Jan. 13, 1993, Arts. 15(4)-(5), 32 ILM 800, 820 (1993) (rapid amendment procedure for annexes listing materials subject to the Convention's controls); UN Convention against Illicit Traffic in Narcotic Drugs and Psychotropic Substances, Dec. 20, 1988, Arts. 12(5)-(6), UN Doc. E/CONF.82/15, 28 ILM 493 (1989) (same). The rapid amendment procedure allows regimes to respond more flexibly both to new scientific knowledge and to new environmental problems. If a species becomes endangered, for example, the parties to CITES can vote to include it in Appendix I, thereby prohibiting commercial trade, without waiting for the affirmative consent of each CITES party.

But, as some critics have noted, rapid amendment procedures promote flexibility at the expense of consensual legitimacy. See Karl Kaiser, Transnational Relations as a Threat to the Democratic Process, 25 INT'L ORG. 706 (1971); David A. Koplow, When Is an Amendment Not an Amendment?: Modification of Arms Control Agreements Without the Senate, 59 U. CHI. L. REV. 981, 1069-72 (1992). Under rapid amendment procedures, the decision whether or not to object is ordinarily made by the executive rather than the legislative branch. The upshot is that new environmental standards can be adopted and come into effect, without the explicit consent of the legislature. For an attempted justification, see Note, Discretion and Legitimacy in'International Regulation, 107 HARV. L. REV. 1099 (1994). 
scientists have proposed innumerable theories of legitimacy, generally these can be grouped into three basic types: source-based, procedural, and substantive.

- First, authority can be legitimated by its origin or source-because it comes from God, for example, or tradition. Until relatively recently, authority often had a religious basis: rulers claimed to rule by divine right or to have a mandate from heaven. In medieval times, custom played a significant role. ${ }^{88}$ More recently, many writers have attempted to found political authority on consent-for example, state consent to treaties, which we have already considered. ${ }^{89}$

Second, authority can be legitimate because it involves procedures considered to be fair. ${ }^{90}$ Both judicial and administrative authority have traditionally been legitimated, at least in part, in procedural terms. ${ }^{91}$ Judicial legitimacy, for example, depends on such procedures as the right to be heard, to confront witnesses and to an impartial judge. Similarly, the U.S. Administrative Procedure Act requires administrative agencies to provide the public with notice of proposed rules, to give them the opportunity to make comments, and to provide a fair and open hearing.

Finally, authority can be legitimated by its success in producing desired outcomes-for example, economic welfare, social justice, or, in our case, environmental protection. Alexander Pope expressed this view succinctly: "Over forms of government let fools contest, whatever is best administered is best." 92 People may accept a regime's decision in a particular case, even if they are not convinced that the decision is correct, ${ }^{93}$ if they believe the regime has generally done a good job and therefore is justified in its right to govern. The success of the U.S. Federal Reserve in promoting sustained economic growth, for example, hàs helped build its legitimacy. Conversely, the failure of the League of Nations to address Italian aggression in Ethiopia led to a loss of legitimacy. ${ }^{94}$

In the following sections, I will begin by examining democracy as a possible basis of legitimacy, and will then survey two other factors that can contribute to the legitimacy of international environmental law: public participation and expertise.

\section{Democracy as a Basis of Legitimacy}

In the modern world, democracy has become the hallmark of legitimate government. ${ }^{95}$ A 1949 UNESCO study found that "for the first time in the history of the world, no doctrines

\footnotetext{
${ }^{88}$ In medieval times, the term "legitimus" meant in essence, conforming to ancient custom. Sternberger, supra note 48 , at 245 .

${ }^{89} \mathrm{But}$, as Partridge notes, although we sometimes think of consent theory as a recent development, "some sort of notion of consent . . . has been present throughout virtually the whole history of political speculation." PARTRIDGE, supra note 75, at 10. Consent theory was prominent, for example, in antiquity, and, during the middle ages, the idea was "ubiquitous" that "supreme political authority, even though it may be, in some sense, 'of God,' was made legitimate by the free consent or acceptance of 'the people." Id. at 14.

${ }^{90}$ See FRANCK, supra note 3 (emphasizing "right process"); TYLER, supra note 43; Wirth, supra note 9, at 798 ("[P] rocedural integrity is itself an important source of authority and legitimacy for international law.").

${ }_{91}$ SeeJoint Anti-Fascist Refugee Comm. v. McGrath, 341 U.S. 123, 149, 171 (1951) (Frankfurter, J., concurring) (legitimacy of administrative decisions has procedural basis), quoted in Wirth, supra note 83, at 186. Another possible basis for the legitimacy of administrative law is expertise, an argument that Majone has emphasized in the European Union. See notes $152-68$ and corresponding text.

${ }^{92}$ An Essay on Man, III, line 303.

${ }^{93}$ Indeed, if they were convinced, we would not need to speak of authority or legitimacy at all.

${ }^{9}$ It may be that the latter relation is more important than the former: a regime may not need to be notably successful in order to be deemed legitimate, but if it is an abject failure, then this undermines its legitimacy. See Caron, supra note 3, at 559-61 (failure of an institution to deliver on its promises and goals can give rise to perceptions of illegitimacy).

${ }^{95}$ This is a relatively recent phenomenon. Historically, governments usually claimed some other basis of legitimacy-divine right, tradition, or rule by the natural elite, to name a few. See DAVID HEL), MODELS OF DEMOCRACY (1987). As C. B. Macpherson observes, "Democracy used to be a bad word. Everybody who was anybody knew that democracy, in its original sense of rule by the people or government in accordance with the will of the bulk of the people, would be a bad thing - fatal to individual freedom and to all the graces of civilized living. That was the position taken by pretty nearly all men of intelligence from the earliest historical times down to about a hundred years ago." C. B. MACPHERSON, THE REAL WORLD OF DEMOCRACY 1 (1966).
} 
are advanced as anti-democratic." 96 To attach the label "democratic" to one's views is to legitimate them, and to label a regime "undemocratic" is to question its legitimacy. Thus, not surprisingly, claims are sometimes made that international environmental law needs to become more democratic.

But while everyone praises democracy, they do not necessarily mean the same thing by the term. ${ }^{97}$ Does democracy, for example, require that the people govern directly (popular democracy) or can they govern by electing representatives (representative democracy)? Is the scope of democracy limited to politics, or does it extend to economic and social life? ${ }^{98}$ Does democracy imply majority decision making? Does it serve merely as a means of aggregating private preferences, or should it involve deliberation about the public good? ${ }^{99}$ Opinions vary widely about these and other issues. As a result, Stanley Benn observes, "what one person would regard as a paradigm case [of democracy] another would deny was a democracy at all." 100

The justifications of democracy also vary widely. Indeed, democracy can be conceptualized and justified in terms of all three types of legitimacy I mentioned earlier: source-based, procedural, and substantive. It is based on the consent of the governed, expressed through regular, free elections, in which leaders can be replaced and policies changed. It involves fair procedures (universal suffrage, majority voting, political equality). And arguably it produces the best results-either because, as Jefferson argued, "in the end, the people are wiser than any single individual can be," or because democracy best aggregates individual interests, as the utilitarians believed, thereby maximizing social welfare (an approach now questioned by public choice theorists). ${ }^{101}$

In international law, the term "democracy" has been used in at least three different senses. First, "democracy" can have essentially the same meaning internationally as it does domestically-that is, a system of government based on popular elections and majority voting. ${ }^{102}$ Alternatively, it can mean political equality among states-that is, the rule of "one state, one vote," as opposed to weighted voting. This is what developing countries apparently have in mind when they call for more "democratic" decision making in international institutions such as the World Bank or the IMF. ${ }^{103}$ Finally, some environmental advocates use the term "democracy" to refer to various features of open government, in particular, transparency and public participation. ${ }^{104}$

The last two usages, however, are at best questionable. Democracy, if it has any meaning at all, means "rule by the people." So labeling the "one state, one vote" rule "democratic"

\footnotetext{
${ }^{6}$ R. MCKEON, DEMOCRACY IN A WORLD OF TENSIONS 522 (1951).

${ }^{97}$ Bertrand de Jouvenal has argued that "discussions about democracy . . . are intellectually worthless because we do not know what we are talking about." BERTRAND DEJOUVENAL, Du POUVOIR 338 (1947), quoted in GIOVANNI SARTORI, THE THEORY OF DEMOCRACY REVISITED 6 (1987).

${ }^{98}$ See, e.g., CAROL C. GOULD, RETHINKING DEMOCRACY: FrEEDOMANDSOCIAL COOPERATION IN POLITICS, ECONOMY AND SOCIETY (1988) (arguing for a broader conception of democracy that applies to economic and social life).

${ }^{9}$ Deliberative Democracy: Essays on Reason AND Polttics (James Bohman \& William Rehg eds., 1997); DEMOCRACY AND DIFFERENCE: CONTESTING THE BOUNDARIES OF THE POlTTICAL (Seyla Benhabib ed., 1996).

${ }^{100}$ Stanley I. Benn, Democracy, in 2 ENCYCloPedia of Philosophy 338, 338 (Paul Edwards ed., 1967).

${ }^{101}$ Environmental politics provides empirical support for a substantive justification of democracy since Western liberal democracies have done a demonstrably betterjob of protecting the environment than the non-democratic regimes of the former Soviet Union and Eastern Europe. Robert Paehlke, Environmental Challenges to Democratic Practice, in Democracy aNd THE ENVIRONMENT: Problems and Prospects 18, 19 (William M. Lafferty \& James Meadowcroft eds., 1996).

${ }^{102}$ See, e.g., FRANCK, supra note 27, at 482-84; HELD, supra note 25, at 269-74.

${ }^{103}$ See, e.g., Andrew Jordan, Paying the Incremental Costs of Global Environmental Protection: The Evolving Role of GEF, ENV'T, July-Aug. 1994, at 12, 18, 33 (comparing more "democratic" UN voting rules with less "democratic" Bretton Woods approach); see also Charles N. Brower, Compliance with International Law, 1997-1998PROC.AM. BRANCHINT'L LAW ASS'N 70, 71 (1998) ("[T] he international community is a democratic one. ... [I]t is indeed, 'One State, one vote."').

${ }^{104}$ See, e.g., Daniel Magraw, NAFTA's Repercussions: Is Green Trade Possible, ENv'T, Mar. 1994, at 14, 41 (equating greater transparency and public participation with "democratization"); Wirth, supra note 9.
} 
is a misuse of the term. Such a voting rule may or may not be desirable, but this question should be considered on its own merits, without seeking the imprimatur conferred by the term "democratic." Indeed, from a democratic perspective, the "one state, one vote" rule is, if anything, illegitimate, since it gives individuals in small states a greater influence on decision making than individuals in large ones, and it creates the possibility that decisions could be made by states representing a tiny fraction of the world's population. ${ }^{105}$

Supporters of the "one state, one vote" rule usually cite as justification the principle of sovereign equality ${ }^{106}-$ a basic axiom of the traditional system of international law, which, in essence, transposed liberalism to inter-state relations. ${ }^{107}$ According to this view, states-like individuals - are free and equal in the state of nature. ${ }^{108} \mathrm{Just}$ as individual equality implies the principle of "one person, one vote," sovereign equality justifies the "one state, one vote" rule. ${ }^{109}$ The problem with this reasoning is that it fails to provide any justification for the initial equation of states and individuals. In liberal theory, the right of individuals to equal respect flows from the fundamental character of personhood. But there is nothing fundamental about the state; it is merely a social and historical construct, which exists to serve human ends. Even supporters of states rights would generally agree that these rights are merely means to some other end, such as stability or order, not ends in themselves. Thus, there is no intrinsic reason to treat states as equals. Nor is there any equitable reason, given the actual disparities among states in population, power, and wealth. To put it bluntly, why should Nauru, with a population of approximately seven thousand, have an equal say in global issues as China or India, with populations one hundred thousand times as large? Why should the Alliance of Small Island States have forty-two votes in the United Nations, while the United States, comprising fifty semi-sovereign states and a population more than ten times as large, has only one?

Rules promoting transparency and public participation are more justifiably styled "democratic," since they focus on the relation of the state and the individual. Indeed, given the importance of transparency and participation to democracy, it is to some degree a semantic question whether we choose to attach the adjective "democratic" to them. And yet, while these procedural protections are important, democratic government involves not simply public participation, but the ability of the public to make decisions, either directly or through the election of representatives. Without elections, it is difficult to consider a government as "democratic." For this reason, I will consider the legitimating effect of transparency and public participation separately. ${ }^{110}$

If we take as our definition of democracy a political system with popularly-elected, representative bodies and majority decision making, then, at present, the one international institution that remotely fits this description is the European Parliament. ${ }^{111}$ For this reason, the European Parliament is commonly viewed "as the only (or at least principal) repository

\footnotetext{
${ }^{105}$ See Inis L. Claude, JR., Swords into Plowshares: The Problems and Progress of International ORGANIZATION 133 (2d ed. 1959).

${ }^{106}$ See generally R. P. Anand, Sovereign Equality of States in International Law, 197 RECUEIL DES Cours 9 (1986 II).

${ }^{107}$ The link between sovereign equality and liberal theory is apparent in Pufendorf, who in essence argued, "All persons in a state of nature are equal; the persons of international law are in a state of nature; therefore they are equal." P. J. Baker, The Doctrine of Legal Equality of States, 1927 BRIT. Y.B. INT'L L. 1, 6; see also HENKIN, sufra note 46 , at 104-05 (discussing relationship of international law and liberal theory).

${ }^{108}$ Compare JOHN LOCKE, SECOND TREATISE OF GOVERNMENT II, \$4 (the state of nature is "a State of perfect Freedom . . . and a State also of Equality") with Declaration on Principles of International Law Concerning Friendly Relations and Cooperation among States, GA Res. 2625, UN GAOR, 25th Sess., Supp. No. 28, at 121, UN Doc. A/8028 (1971) (principles of sovereignty and sovereign equality).

${ }^{109}$ But see KOO, supra note 74, at 8 ("one state, one vote" rule doesn't necessarily follow from sovereign equality).

${ }^{110}$ See notes 132-51 and corresponding text.

111 Robert A. DahI, A Democratic Dilemma: System Effectiveness Versus Citizen Participation, 109 POL. ScI. Q. 23, 32 (1994) (with the exception of the European Union, "no transnational structures exist with even the semblance of a democratic process").
} 
of legitimacy and democracy" in the European Union. ${ }^{112}$ Much of the concern about the European Union's "democratic deficit" stems from the weakness of the Parliament relative to the European Council and Commission. Although the Maastricht Treaty strengthened the Parliament's role (establishing a "co-decision" procedure that gives it a veto on certain legislation ${ }^{113}$ ), the Parliament still does not have the powers of a national legislature, and is excluded from large areas of EU activity, including foreign and security policy and the fields of justice and home affairs (the so-called second and third "pillars" of the EU). ${ }^{114}$

Just as making the European Union more democratic is often viewed in terms of strengthening the European Parliament, making international environmental law more democratic might entail establishing popularly-elected international bodies with either general or limited decision-making powers. Proposals along these lines include those by David Held to create an "independent assembly of democratic peoples"115 and by Hilary French to establish a body composed of representatives of national parliaments, perhaps as a transition to a popular assembly. ${ }^{116}$

Such proposals are, of course, unrealistic. But the more interesting point is that the proposed institutions would suffer a legitimacy deficit. First, a global legislature would raise the problem noted by Rousseau long ago, namely that, as the scale of government increases, the opportunities for citizen participation decrease. ${ }^{117}$ In the United States, the perception that Washington is remote and unresponsive to local concerns has prompted a transfer of governmental functions back to the states. Similarly, the fear that EU institutions in Brussels or Luxembourg can override the democratically-adopted choices of member states has produced a backlash-a desire for greater local control-reflected in the principle of subsidiarity. ${ }^{118}$ But, if EU institutions seem remote from ordinary citizens, and opportunities to influence decisions difficult, these problems would be nothing compared to the remoteness of a global legislature.

Second, the legitimacy of democratic rule depends on the existence of a "demos"-a shared sense of community-which is absent at the global level. Why is a demos essential to the legitimacy (and indeed the possibility) of democratic government? The answer has to do with the nature of democratic decision making, and in particular majority voting. The principle of majority rule has always posed a problem for democratic theorists, who have difficulty justifying why a minority should be bound by the majority will? If one takes a purely individualist perspective, the problem appears insoluble. ${ }^{119}$ "To get the individual citizen to identify with the regime," Pennock observes, "to feel that its interest is his interest, that his little share of sovereignty (especially if he was in the minority!) amounts to anything and makes it either his duty or his interest to put himself out for the sake of helping the

\footnotetext{
112 Weiler, supra note 73 , at 2466.

${ }^{113}$ Treaty on European Union, Feb. 7, 1992, Art. 189b, 1992 O.J. (C 224) 1, 31 ILM 247 (1992).

114 For example, the co-decision procedure applies to only about $25 \%$ of the European Union's legislative activity, rather than to all EU legislation. GERDA FAI KNER \& MICHAEL NENTWICH, EUROPEAN UNION: DEMOCRATIC PERSPEGTIVES AFTER 1996, at 8 (1995). The 1997 Amsterdam Treaty would significantly expand the spheres subject to the co-decision procedure. See Sally Langrish, The Treaty of Amsterdam: Selected Highlights, 23 EUR. L. REV. 3 (1998).

115 DAVID HeLD, Prospects For DEMOCRACY 274 (1993).

${ }^{116}$ French, supra note 13 , at 50.

${ }^{117}$ Dahl, supra note 111, at 29-30.

${ }^{118}$ In the European Union context, Joseph Weiler has referred to this problem as "inverted regionalism." Weiler, supranote 10 , at 6 . The desire to keep government "close to the people" provides a "democratic" argument against EU competence, independent of the democratic (or undemocratic) nature of EU governance itself. As Weiler argues, "even if the Union were to replicate in its system of governance the very same [i.e., democratic] institutional set-up found in its constituent states, there would be a diminution in the specific gravity, in the political weight, in the level of control of each individual within the redrawn political boundaries." Supra note 10 , at 6.

119 See Robert Paul. WOLF, IN DEFEnSE OF ANARchism (1970).
} 
system function-is a large order." 120 The minority does not consent to the majority's decision, so consent theory fails to justify majority rule. The principles of self-determination and individual autonomy also do not justify majority rule, since the minority is bound by the majority's will and is unable to determine its own fate. Instead, majority decision making depends on the idea that both the majority and minority are part of a common community-a demos that is more than just a "random assortment of people." a "foundation not only of shared values, but also of shared experience, so that people identify with the political system to which they belong, and can trust its procedures and their outcomes."122

Prior to the eighteenth century, most political theorists believed that a democratic community could exist only in a small city-state. ${ }^{123}$ Aristotle, for example, thought that "the range of an unamplified human voice" set a limit on a democracy's size. ${ }^{124}$ The establishment of the United States demonstrated that democracy is also possible in a large nation-state. In the debate about the European Union's democratic deficit, a critical question has been whether the European Union represents the kind of community that can be governed by a democracy-whether there is a European demos. In its so-called Maastricht decision, the German Constitutional Court answered no, advancing what Joseph Weiler has called the "no-demos" thesis. ${ }^{125}$ According to the Court, a democratic polity depends on a "sense of social cohesion, shared destiny and collective self-identity," which in turn is "conditioned on some, though not necessarily all, of the following objective elements: common language, common history, common cultural habits and sensibilities and . . . common ethnic origin, common religion."126 The German Court concluded that these conditions are still absent at the European level. In contrast, Joseph Weiler has taken a more positive view. He objects to the German Court's Volkish conception of the demos. He suggests instead a civic, non-ethno-cultural alternative, predicated on the legal concept of citizenship. ${ }^{127}$

But whether we take the more restrictive view of the German Constitutional Court or Weiler's more expansive approach, in neither case is there anything approaching a demos internationally. ${ }^{128}$ Theoretically, such a demos could develop. Nevertheless, as a practical matter, the diversity of cultures, religions, social and economic conditions, and histories makes the prospects for a global demos exceedingly dim. Weiler asks us to imagine the "screams of grief" of Danes, if Denmark were absorbed by Germany and Danes were consequently bound by the decisions of the German majority in the Bundestag. ${ }^{129}$ But these screams would be nothing compared to those that a global legislative body would provoke. Why would Americans, Swiss, Japanese, Saudis or Nigerians feel bound by the decisions of a foreign majority concerning permissible levels of carbon dioxide emissions, or measures to protect biological diversity? Why would they view a majority decision-making procedure

${ }^{120} \mathrm{~J}$. ROLAND PENNOCK, DEMOCRATIC POLITICAL THEORY 213 (1979).

121 ELAINE SPITZ, MAJORTTY RULE 151-52 (1984).

${ }^{122}$ ANTHONYARBI ASTER, DEMOCRACY 78 (1987); see also ROBERT D. PUTNAM, MAKING DEMOCRACYWORK (1993); SANDEL, supra note 20, at 5 (democracy depends on "a sense of belonging, a concern for the whole, a moral bond with the community whose fate is at stake"); CLAUDE, supra note 105, at 137-38; Fritz Scharpf, Legitimacy in the European Union (1998) (unpublished manuscript, on file with author) (majority rule depends on "Ihick" identity, i.e., commonalities of history, language, culture and ethnicity that make people trust in the benevolence of their fellow citizens).

${ }^{123}$ See generally ROBERT A. DAHL \& EDWARD R. TUFTE, SIZE AND DEMOCRACY (1973).

${ }^{124}$ Id. at 5 .

${ }^{125}$ Weiler, supra note 10 , at 10.

${ }^{126}$ Id. at 11 .

${ }^{127}$ Id. at $17-19$.

${ }^{128}$ This is true not only of individuals but of states, which helps explain why majority decision-making procedures remain exceptional and are used only when "a common interest has been recognized [among states] and fundamental principles have been agreed upon." RicHES, supra note 60, at 297.

${ }^{129}$ Weiler, supra note 10, at 12. 
as legitimate? And, from a normative perspective, why should they? These are questions for which our understanding of democracy provides no good answers. ${ }^{130}$

Of course, democracy has a vital role to play at the domestic level: making foreign policymaking more democratic would help ameliorate the concerns identified earlier about specific state consent and give international environmental law greater legitimacy vis à vis individuals. ${ }^{131}$ But, between states, democracy does not offer a real alternative to consent. For the moment, democracy, like charity, must begin at home.

\section{Democratic Legitimacy and Public Participation}

The difficulties of applying democratic theory at the international level have prompted some to focus on one particular aspect of democracy, namely public participation. ${ }^{132}$ Like democratic legitimacy, participatory legitimacy takes a "bottom-up" approach, basing governmental legitimacy on the preferences and the participation of the governed. But, in contrast to democratic governance, the governed do not wield decision-making authority; rather, their influence is more partial and diffuse.

Participation can contribute to popular legitimacy by giving stakeholders a sense of ownership in the process. ${ }^{133}$ Conversely, restricted participation can provoke dissatisfaction on the part of those excluded. For example, the Antarctic Treaty's requirement that states must engage in substantial activities in the Antarctic in order to become full participants in the regime-a requirement that effectively raises the price of membership-has been the principal basis on which developing countries have challenged the regime's legitimacy. ${ }^{134}$ Similarly, the lack of effective participation, initially, by developing countries in the Intergovernmental Panel on Climate Change (IPCC) raised legitimacy concerns and led to the establishment of an ad hoc working group to encourage greater developing country involvement. ${ }^{135}$ Indeed, in the climate change regime, the demand for universal participation has had the somewhat curious result that all of the parties to the UN Framework Convention on Climate Change were allowed to participate in (and potentially obstruct) the Kyoto Protocol negotiations, even though from the outset, it was agreed that the Protocol would impose limitations on only a small subset of states, namely industrialized countries. $^{136}$

\footnotetext{
${ }^{150}$ A related problem with global democracy would be the difficulty of providing information to so many people, so that they can make informed choices. Democracy is more than the mere aggregation of individual wills; it involves deliberation about the public good, which becomes progressively more difficult as the scale of the polity increases. Dahl, supra note 111, at 30.

${ }^{131}$ See supra notes 77-87 and accompanying text.

132 See, e.g., DANIEL C. ESTY, GREENING THE GATT: TRADE, ENVIRONMENT AND THE FUTURE 94 (1994) (stressing need for transparency); Jeffrey L. Dunoff, Institutional Misfits: The GATT, The ICJ E Trade-Environment Disputes, 15 MICH.J. INT'L L. 1043, 1117 (1994) (institutional legitimacy enhanced by transparent procedures and decisionmaking processes); Daniel J. Fiorino, Environmental Poligy and the Participation Gap, in DEMOCRACY AND THE ENVIRONMENT:PROBLEMSAND PROSPECTS 194 (William M. Lafferty \& James Meadowcraft eds., 1996); Kate O'Neill, Out of the Backyard: The Problems of Hazardous Waste Management at a Global Level, 7J. ENV'T \& DEv. 138, 159 (1998) (equating citizen participation with legitimacy); Wirth, supra note 9 . Transparency and public participation are, of course, not the only possible bases of procedural legitimacy. Due process protections, for example, tend to focius instead on fundamental fairness.

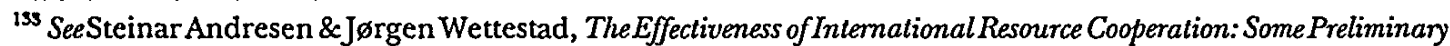
Notes on InstitutionalDesign, 13 INT'L CHALI ENGES61,67 (1993) (participation by key stakeholders such as scientists, industry representatives and environmentalists increases legitimacy of international environmental regimes).

${ }^{134}$ See supra note 49 and accompanying text.

${ }^{135}$ Intergovernmental Panel on Climate Change, Report of the 2nd Sess., June 28-30, 1989, Annex III.

${ }^{136}$ OfFICE OF TECHNOLOGY ASSESSMENT, Climate TREATIES AND MODELS: ISSUES IN THE INTERNATIONAL MANAGEMENT OF CLIMATE ChANGe, OTA-BP-ENV-128, at 4 (1994) ("[I]f the entire endeavor is to be seen as legitimate, it must represent a broad international consensus, possibly including most nations of the world.").
} 
In the European Union, lack of public participation has been one of the principal elements of the democratic deficit critique. ${ }^{137}$ The arcane and often opaque quality of EU governance makes participation difficult. Renaud Dehousse notes that, under the Maastricht Treaty, "no [fewer] than 21 different procedures can currently be used by European institutions" to make decisions, and the work of the Council continues to be "shrouded in secrecy." Similarly, Juliet Lodge describes the popular perception of the Commission's proposals as "impenetrable" and its practices and personnel as "byzantine, inaccessible and an affront to the conduct of democratic politics." ${ }^{139}$ The transparency deficit is perhaps even worse on the implementation and enforcement side, where the use of committees to elaborate and apply standards (known in EU parlance as "comitology") is notoriously obscure. ${ }^{140}$ Indeed, so opaque is the comitology system that apparently no one can even say for certain how many committees exist, let alone how they operate.

In contrast to the European Union's democratic deficit, the problem of public participation in the European Union is more easily redressed. Without a European demos, democratic legitimacy may be impossible to attain. But the European Union's procedural legitimacy could be enhanced simply by opening up Council deliberations, providing greater notice of legislative proposals, clarifying and streamlining the comitology process, and giving the public a greater opportunity to participate. ${ }^{141}$ Drawing on the model of U.S. administrative law, for example, Dehousse has suggested the adoption of a European administrative procedure act, which would require committees to publish their agenda and minutes and grant interested parties the right to express their views. ${ }^{142}$

In recent years, environmentalists have begun to echo the complaints heard within the European Union, and to call for greater access to information and public participation in international environmental regimes. ${ }^{143}$ States have tended to try to confine the issue to national decision making, ${ }^{144}$ but NGOs have pushed for greater openness and access in international fora as well. In part due to their efforts, the recently-adopted Åarhus Convention contains a provision requiring parties to promote transparency and participation in "international environmental decision-making processes and within the framework of international organizations in matters relating to the environment." 145

${ }^{137}$ Deirdre Curtin, The Constitutional Structure of the Union: A Europe of Bits and Pieces, 30 COMMON MKT. L. REV. 17, 38-39 (1993) ("labyrinthine complexity of the decision-making process" is "one of the main causes of the persisting 'democratic deficit'); see also Deirdre Curtin \& Herman Meijers, The Principle of Open Government in Schengen and the European Union: Democratic Retrogression?, 32 COMMON MKT. L. REV. 391, 440 (1995); Juliet Lodge, Transparency and Democratic Legitimacy, 32 J. COMMON MKT. STUD. 343 (1994).

${ }^{138}$ Dehousse, sufra note 10, at 123. The 1997 Amsterdam Treaty simplified the range of legislative procedures, eliminating in large part the cooperation procedure and streamlining the co-decision procedure.

139 Lodge, supra note 137 , at 345 .

${ }^{140}$ Weiler wryly comments that "comitology is an apt neologism-a phenomenon that requires its very own science, which no single person has mastered." Weiler, supra note 10 , at 9 .

${ }^{141}$ Curtin \& Meijers, supra note 137, at 440; De Búrca, supra note 10, at 368-71; Renaud Dehousse, Toward the Regulation of Transnational Governance? Citizens' Rights and the Reform of Comitology Procedures, at 6 (1998) (unpublished manuscript, on file with author); Majone, supra note 10, at 20-21 (focusing on transparency, the need to justify decisions and judicial review, as elements of procedural legitimacy).

${ }^{142}$ Dehousse, supra note 141.

143 See generally Ebbesson, supra note 15; Neil A. F. Popovic, The Right to Participate in Decisions that Affect the Environment, 10 PACE ENVTL. L. REV. 683 (1993); Kal Raustiala, The "Participatory Revolution" irm International Environmental Law, 21 HARV. ENVTL. L. REV. 537 (1997).

${ }^{144}$ See, e.g., Rio Declaration on Environment and Development, princ. 10, UN Doc. A/CONF.151/26 (1992), - reprinled in 31 ILM 874 ("Environmental issues are best handled with the participation of all concerned citizens, at the relevant level. At the national level,"each individual shall have appropriate access to information concerning the environment that is held by public authorities . . . and the opportunity to participate in decision-making processes."). David Wirth observes that " $[$ a]n explicit call for direct public participation in international processes is notably absent from this exhortation." Wirth, supra note 9 , at 773 .

${ }^{145}$ Aarhus Convention on Access to Information, Public Participation in Decision-Making and Access to Justice in Environmental Matters, June 25, 1998, Art. 3(7), UN Doc. ECE/CEP/43, 38 ILM 517 (1999); Brady, supra note 15. 
The emerging administrative process in international environmental law has prompted particular concerns about participation. Increasingly, international standards are being elaborated, not through international negotiations, but by public and private expert groups-for example, the Codex Alimentarius Commission (Codex) (which sets food safety standards) ${ }^{146}$ and the International Organization for Standardization (ISO) (which has developed environmental management standards) ${ }^{147}$ Although the decisions of these harmonization bodies are not binding and states are, in theory, free to accept or reject them, in practice the harmonization bodies have a significant influence on the domestic regulatory process since the GATT Uruguay Round Agreements give them a privileged position. If a state's domestic standard follows the international standard, then the domestic standard is presumed to be in compliance with the GATT; the international standard, in effect, provides a safe harbor. In contrast, if a national standard departs from the international standard, then it is vulnerable to challenge as an unfair trade practice, unless the state can justify its standard as scientifically based. The question is whether the ISO and the Codex provide the type of procedural protections that we expect of domestic administrative rulemaking, which are intended to ensure transparency and adequate opportunities for public participation. Like comitology in the European Union, the fledgling administrative process in international environmental law is often opaque, and has involved little public participation. National government experts, assisted by industry advisors, play the leading role in the EU committees and the Codex, whereas business representatives play the leading role in the ISO. ${ }^{148}$ Administrative procedure requirements such as notice and comment rulemaking would provide at least some measure of accountability to the public and therefore have the potential to serve the same legitimating functions as they do domestically.

But although public participation could be an important source of international legitimacy, it also has several limitations. To begin with, in speaking of participation by "the public," we are indulging in a bit of a euphemism. What is meant more precisely is participation by non-governmental groups such as Greenpeace, the Sierra Club, and the Global Climate Coalition, which often have opposing positions and may or may not reflect the "public interest"-if such a thing exists at all. ${ }^{149}$ Indeed, even if international meetings were opened up and NGOs given unrestricted access, few members of the public would as a practical matter be able to participate. ${ }^{150}$

Moreover, transparency and public participation confer a relatively weak form of legitimacy since they do not affirmatively justify the decisions made by international regimes. As one writer notes, "The goal of public participation ... is not to transfer the actual decision-making power over the formulation and adoption of rules to the interested public, but only to assure an adequate opportunity for interested persons to communicate their views and information to the appropriate ... officials." 151

\section{Expertise as a Basis of Legitimacy}

In large part we judge an institution by its fruits. In its early years, for example, the apparent ability of the European Union to "deliver the goods"-to contribute to peace and

\footnotetext{
146 See supra note 17.

${ }^{117}$ See supra note 16.

${ }^{118}$ Roht-Arriaza, supranote 16, at 526 (domination of ISO by large corporate interests and industrialized-country delegations are potential sources of lessened legitimacy).

${ }^{149}$ See Peter J. Spiro, New Global Potentates: Nongovernmental Organizations and the "Unregulated'Marketplace," 18 CARDOZO L. REV. 957 (1996).

${ }^{150}$ See Fiorino, supra note 132, at 209 (likelihood of effective participation declines as decision making further away from those affected).

${ }^{151}$ Arthur Earl Bonfield, The Federal APA and State Administrative Law, 72 VA. L. REv. 297, 319 (1986).
} 
prosperity-helped its popular legitimacy. In the environmental arena, the Antarctic Treaty System (ATS) is an example of a regime claiming substantive legitimacy. In response to criticisms by developing countries, the Antarctic Treaty Consultative Parties (A.TCPs) have pointed to the regime's 40 -year record of success in preserving Antarctica as a zone of peace and science-a record that they argue justifies continuing the current system. ${ }^{152}$

The substantive success of a regime might be judged in different ways and have various origins. Some writers, for example, have justified democracy on the grounds that it produces the best substantive results. An alternative tradition, dating back to Plato, focuses on expertise as a source of legitimacy. ${ }^{153} \mathrm{Just}$ as we rely on expertise rather than democratic decision making to build airplanes and to cure diseases, we might believe that, if economists were to make economic decisions and environmental experts environmental decisions, this would lead to the best outcomes. Indeed, it is precisely this desire to have monetary issues decided by financial experts that underlies the effort to insulate the U.S. Federal Reserve Board and the new European Central Bank from politics.

Expert decision making stands in sharp contrast to public participation. The fact that both are sources of legitimacy reflects the fact that people want government institutions to be both effective in solving problems and subject to public control. ${ }^{154}$ As C. E. Lindblom noted,

On the one hand, people want policy to be informed and well-analyzed. On the other hand, they want policymaking to be democratic ... In slightly different words, on the one hand they want policymaking to be more scientific; on the other, they want it to remain in the world of politics. ${ }^{155}$

In the domestic arena, the legitimacy of administrative agencies is often defended in terms of expert legitimacy, on the ground that administrative agencies perform a primarily technical role, requiring expert knowledge, in advancing the values and goals set forth in legislation. As Majone observes, government regulators try to "wrap [their decisions] in a cloak of scientific respectability." "In international environmental law as well, virtually every regime has a strong scientific component.

The model of expert decision making rests on three premises: first, the decisions in question have better and worse answers; second, certain people possess special knowledge (expertise) about what those answers are; and third, we (the non-experts) can identify the people with this special knowledge. ${ }^{157}$ For example, certain levels of whaling are sustainable and others are not; some people possess specialized knowledge that allows them to calculate the sustainable levels; and we can identify the people with this specialized knowledge.

Often, the third premise poses the biggest hurdle. Identifying who qualifies as an expert has been the stumbling block in the debate about the safety of nuclear power, where one "expert" is pitted against another, and each side claims that the other's opinions are based on politics, not science. One of the significant accomplishments of the climate change regime has been the development of a process for engaging the best expert opinion about

\footnotetext{
152 See Jørgensen-Dahl, supra note 49; GOVERNING THE ANTARCTIC, supra note 49.

${ }^{159}$ Plato, ProtagoRas, \$319b (W.K G. Guthrie trans., 1956), reprinted in ThE COLlected Dlalogues OF Plato 317 (Edith Hamilton \& Huntington Cairns eds., Princeton Univ. Press 1961). For a more recentaccount that bases legitimacy on expertise, see Majone, supra note 10. The use of the term "authority" to mean "expert" (as in, "Kugel is an authority on the Bible") reflects the close connection between authority and expertise.

${ }^{154}$ SeeWilliam C. Clark \& Giandomenico Majone, The CriticalAppraisal of Scientific Inquiries with Policy Implications, 10 SCI., TECH. \& HuMAN VAlues 6, 15 (1985).

${ }_{155}^{15}$ C. E. LINDBLOM, THE POLICY MAKING PROCESS $12 \cdot(2 \mathrm{~d}$ ed. 1980), quoted in Clark \& Majone, stipra note 154, at 15 .

${ }^{156}$ Giandomenico Majone, Science and Trans-Science in Standard Setting, 9 SCI., TECH. \& HUMAN VALUES 15, 15 (1984).

${ }^{157}$ David Estlund, Making Truth Safe for Democracy, in THE IDEA OF DEMOCRACX 71 (David Copp et al. eds., 1993).
} 
climate change, through the work of the Intergovernmental Panel on Climate Change (IPCC), a process that states have generally accepted. ${ }^{158}$

But, apart from the problem of separating experts from pretenders, the relationship between scientific expertise and decision making is far from straightforward. Consider the premise that environmental problems have better and worse solutions. Certainly, environmental issues have a factual component, about which there are right and wrong (or at least better and worse) answers. Whether greenhouse gas emissions will cause global warming, for example, and, if so, how much, over what time period, and with what consequences for humans and the environment-these are questions that have objective answers. But these answers do not necessarily determine any particular decision about what to do. First, a problem such as greenhouse warming has numerous causes, to which numerous responses are possible-energy efficiency standards, taxes, tradeable emission allowances, afforestation, education, geoengineering, and adaptation, to name a few. With respect to many of these possible response measures, science can provide us with useful information about feasibility and effectiveness. But, ultimately, the choice among them is a question of policy, not science.

Second, environmental decision making involves questions of value as well as fact. The Framework Convention on Climate Change, for example, has as its "ultimate objective" the stabilization of atmospheric concentrations of greenhouse gases at levels that would prevent "dangerous" anthropogenic interference with the climate system. ${ }^{159}$ But what is dangerous? Science can determine what the probable effects will be of various concentrations of greenhouse gases, but whether these effects are "dangerous" is in part a value question. ${ }^{160}$ The same is true of risk management decisions. Assessing risks is a scientific task, but determining what to do in response requires value judgments about what levels of risk are acceptable. Such decisions require "inferences, choices, and assumptions that themselves reflect policy preferences." 161

Of course, one might believe that these value questions have objective answers about which certain people possess special expertise. Plato, for example, thought that political expertise does exist, and that those with such special knowledge should rule. But today the almost universal view is that people are equally qualified to make political (value) judgments, either because objective answers do not exist (political questions are matters of personal preference) or because no one possesses any special knowledge about these matters. That is one of the principal arguments for government by the people, i.e., democracy, rather than government by experts. Because people (and states) have different interests and different perceptions of what results count as "success," they should decide what to do, not the experts.

Moreover, even with respect to the purely scientific component of environmental decision making, significant uncertainties may preclude an expert answer. Whether anthropogenic emissions of greenhouse gases will cause significant global warming is a scientific question,

\footnotetext{
158 See LEIV LUNDE, SCIENCE OR POLITICS IN THE GLOBAL GREENHOUSE: A STUDY OF THE DEVELOPMENT TOWARDS SCIENTIFIC CONSENSUS ON CLIMATE CHANGE, Fridtjof Nansen Rpt. 1991/8 (1991). Although some states have questioned the work of the IPCC, the 1996 Geneva Ministerial Declaration endorsed the IPCC second assessment reportas "the most comprehensive and authoritative assessment of the science of climate change." UN Framework Convention on Climate Change Conference of the Parties, 2d Sess., UN Doc. FCCG/CP/1996/15/Add.1, at 71.

${ }^{159}$ UN Framework Convention on Climate Change, adopted May 9, 1992, Art. 2, S. TREATY Doc. No. 102-38 (1992), 31 ILM 849 (1992).

${ }^{160}$ See R. H. Moss, Avoiding "Dangerous" Interference in the Climate System: The Role of Values, Science and Policy, 5 Global ENVIL. Change 3 (1995).

${ }^{161}$ David A. Wirth, The Role of Science in the Uruguay Round and NAFTA Trade Disciplines, 27 CORNELL INT'L L.J. 817,834 (1994). As Wirth explains, "a risk assessment may help in setting a standard designed to limit the probability that an individual will develop cancer after a lifetime of exposure to a particular chemical substance to no more than one chance in a million. By contrast, the choice of the one-in-a-million goal-as opposed to, say, zero or one-in-a-thousand-is one of public policy." Id. at 833.
} 
for which an answer exists. Still, no one knows for certain what that answer is. ${ }^{162}$ As a result, decision making depends not only on what is scientifically known about climate change, but also on a non-scientific judgment about how to act in the face of uncertainty. For example, the precautionary principle reflects the now fashionable view that response measures are appropriate if there is a risk of significant, irreversible harm. ${ }^{163}$

For all of these reasons, environmental decision making often raises questions that involve science but cannot be answered in purely scientific terms. As Majone notes, "[f]ar from being an almost mechanical process safely relegated to technicians, the setting of health, safety and environmental standards is in reality a microcosm in which conflicting epistemologies, regulatory philosophies, national traditions, social values, and professional attitudes are faithfully reflected." ${ }^{164}$

The absence of any simple relation between science and action, however, does not negate the importance of scientific expertise in legitimating international environmental law. Even the precautionary principle, properly applied, should rely on science to identify the risks that might warrant a precautionary approach - for example, depletion of the stratospheric ozone layer and climate change; otherwise, there would be no rational basis for determining when precautionary action is warranted. Science cannot answer every question, but environmental regimes should draw on the best available scientific expertise. Their failure to do so undermines their legitimacy, as the controversy about the IWC moratorium on commercial whaling illustrates. ${ }^{165}$ Many international regimes make the need for scientific expertise explicit. For example, the GATT Uruguay Round Sanitary and Phytosanitary Measures (SPS) Agreement requires that national food safety standards be "based on scientific principles" and not be maintained without "sufficient scientific evidence." "In the Beef Hormones case, although the WTO Appellate Body recognized that science does not dictate any particular level of protection, it nonetheless struck down the European Union's beef hormone ban because it was not rationally supported by any scientific studies. ${ }^{167}$

Moreover, although science cannot answer questions of value, expertise can provide a basis of decision making with respect to issues where there is no significant disagreement over values-where people have shared goals and the issue is how to achieve those goals. In such circumstances, an institution's problem-solving effectiveness can give it legitimacy. As Fritz Scharpf argues, such substantive legitimacy (or as he calls it, "output-oriented legitimacy") is easier to achieve than democratic (or "input-oriented") legitimacy. The latter depends on citizens having a "thick" identity-on commonalities of history, language, and

\footnotetext{
${ }^{162}$ Alvin Weinberg has coined the term "trans-scientific" to describe questions like this, which can be asked of science but cannot be answered by science. Alvin Weinberg, Science and Transcience, 10 MINERVA 209 (1972).

${ }^{163}$ See generally INTERPRETING THE PRECAUTIONARYPRINCIPLE (Timothy O'Riordan \& James Cameron eds., 1994).

${ }^{164}$ Majone, supra note 156, at 15; see also Sheila Jasanoff, Skinning Scientific Cats, NEw STATESMAN AND SOCIETY, Feb. 26, 1993, at 29; Karen T. Litfin, Framing Science: Precautionary Discourse and the Ozone Treaties, 24 MILLENNIUM: JOURNAL OF INTERNATIONAL STUDIES 251 (1995).

${ }^{165}$ See, e.g., Milton M. R. Freeman, Science and Trans-Science in the Whaling Debate, in ElEPHANrS AND Wunilis: RESOURCE FOR WHOM? (Milton M. R. Freeman \& Urs P. Kreuter eds., 1994) (criticizing the IWC moratorium on commercial whaling and the UN General Assembly prohibition on driftnet fishing for lack of a scientific basis); Aron, Burke \& Freeman, supra note 51. Note that if the IWC moratorium were based on the moral belief that whaling is wrong, then science would be irrelevant. But, in order to be consistent with the requirements of the Whaling Convention, the claimed basis of the moratorium has been conservationist rather than preservationist.

${ }^{166}$ Agreement on the Application of Sanitary and Phytosanitary Measures, Apr. 15, 1994, arts. 2.2, Marrakesh Agreement Establishing the World Trade Organization, Annex 1A, LEGAL INSTRUMENTS-RESULTS OF THE URUGUAY ROUND. (1994) [hereinafter SPS Agreement]. Under the SPS Agreement, a state may deviate from international food safety standards only if there is a "scientific justification" or the state undertakes a risk assessment that takes into account "available scientific evidence." Id., arts. 3.3, 5.2. Some environmentalists have questioned the SPS Agreement's requirements regarding scientific evidence and justification. See, e.g., Wirth, supra note 161 .

${ }^{167}$ WTO Appellate Body, EC Measures Concerning Meat and Meat Products (Hormones), Jan. 16, 1998, WT/DS26/AB/R, para. 197.
} 
culture that allow people to trust in majority rule. ${ }^{168}$ In contrast, expert legitimacy depends only on "thin" identity-that is, perceptions of common interests. In pursuing common interests, governmental authority is still needed to overcome collective action problems and reduce transaction costs. But since the outcomes can leave everyone better off, they can provide a basis for a regime's substantive legitimacy.

\section{CONCLUSION}

The process of globalization has put mounting strains on the state system. Environmental problems are increasingly escaping the control of individual states and international institutions have often been too weak to step into the breach. The result has been a "decision-making deficit," an erosion in the ability of government to address environmental problems effectively. In the long run, overcoming this deficit will require stronger international institutions and decision-making mechanisms. But, as the case of the European Union illustrates, the stronger the institution, the greater the concern about its legitimacy. Unless the issue of legitimacy is addressed, it is likely to act as a drag on the development and effectiveness of international environmental regimes.

Many factors can contribute to or detract from a regime's legitimacy. Legitimacy is a matter not of all or nothing, but of more or less. ${ }^{169}$ Authority should be exercised in accordance with law and principle (legal legitimacy). The decision-making mechanisms should be transparent and give people an opportunity to participate (participatory legitimacy). Furthermore, decisions should be based on the best scientific expertise (expert legitimacy). But these are minimum conditions. They contribute to legitimacy (and their absence undermines it), but by themselves do not provide a firm basis for legitimacy. They do not address the central problem, which is how decisions should be made when consensus cannot be reached-by whom, using what voting rule, and with what safeguards.

Calls for global environmental institutions with binding decision-making powers are usually criticized as utopian. This is perhaps too mild a criticism. The term "utopian" carries the connotation of desirable; the criticism suggests that global institution with real power would be a good thing, if only states would agree. But this is by no means clear, given the lack of a strong theory of legitimacy. In the absence of a global community, the one compelling candidate, democracy, does not provide an answer. And, at the moment, we lack any persuasive alternative.

What we need, then, is further work on the problem of legitimacy. By raising and clarifying the issue, this article seeks to pave the way for such research. Given the continuing importance of state consent, an important question is whether and how the system of state consent might be reformed, in order to make it more effective in addressing environmental problems and more legitimate vis à vis individuals. Where relatively clear blocs of states exist, for example, constituency voting and double majority requirements might provide a viable alternative to consensus decision making. Already, the Council of the Global Environment Facility may make decisions by a 60 percent majority vote, so long as donor countries representing at least 60 percent of contributions concur. ${ }^{170}$ The premise seems to be that, although states do not, in general, have sufficient mutual trust to accept majority voting, they do have such trust in the other members of their own group (due, for example, to common history, culture, or interests). Such decision-making approaches warrant further exploration.

${ }^{168}$ Scharpf, supra note 122.

${ }^{169}$ See FRANCK, supra note 3, at 26.

${ }^{170}$ United Nations Convention on the Law of the Sea, opened for signature Dec. 10, 1982, Art. 121 (3), 1833 UNTS 3, reprinted in UNITED NATIONS, OFFICIAL TEXT OFTHE UNITED NATIONS CONVENTION ONTHE LAW OFTHESEA WITH ANNEXES AND INDEX, UN Sales No. E.83.V.5 (1983) (entered into force Nov. 16, 1994). 
In addition, we need detailed case studies of the legitimacy of particular environmental regimes, in order to understand how such factors as public participation, scientific expertise, and consent work in particular contexts to help legitimate international governance. What conditions make these factors more or less effective in legitimating a regime? Which combinations of factors work best, and which ones less well? And even if we cannot develop a satisfactory positive theory of legitimacy, can we at least identify more precisely what to avoid, as well as the factors that help make an institution resilient to claims of illegitimacy?

Finally, as international environmental law increasingly influences (or even displaces) domestic law, further study is needed on the relationship between international and domestic policymaking. ${ }^{171}$ In particular, how can we make the international environmental policymaking process more democratic within countries-for example, through the active involvement of legislators and interest groups in the treaty-making process?

Unless some other basis of legitimacy can be found, the continuing centrality of state consent (which remains, by default, the principal source of legitimacy for international environmental law) is likely to limit the possibilities of international governance. When states have common interests, and the issues involved are relatively technical, states might agree to establish institutions with flexible, non-consensus decision-making procedures, as they have done in the ozone regime. In such cases, general consent confers legitimacy initially, and technical expertise helps maintain this legitimacy on a continuing basis. But this approach is unlikely to work for problems such as climate change, where states have a much wider range of interests, and the issues involved are highly political. This is a sobering conclusion, but one that clarifies the challenges that lie ahead for international environmental law.

171 See Wirth, supra note 83. 